\title{
Carl Schmitt's Critique of Liberal International Legal Order Between 1933 and 1945
}

\author{
Anthony Carty*
}

Keywords: Carl Schmitt; colonial racism; European international law; liberal imperialism; racism in Europe; violence of universal organizations.

\begin{abstract}
Carl Schmitt was an intellectual who made the discipline of international law grapple with the major issues of his time. His work as an international lawyer remains largely untranslated. It is riddled with racism and anti-Semitism. However, an interest of his work is that it reflects the 'shadow side' of contemporary international law, forgotten because the moral defeat of Germany in 1945 was so total. Schmitt argues for an inherent tendency to violence and demonization in Western liberal international law theory and practice. He argues for the acceptance of difference as against homogeneity in world society as the only way to limit this violence. Finally, he argues that the liberal tradition is fundamentally compromised by its own colonialist heritage. Its objections to Nazi Germany translating this colonialist imperialism onto Eastern Europe are incoherent. Schmitt's avowed racism and antiSemitism remain shocking. The article does not try to downplay this aspect of his work. However, it is worth noting that his Nazi bosses, for the most part, thought his racism insincere. If any negative spirit imbues the actual technical detail of Schmitt's work it is his aversion to the West. This probably had its roots in the envy which the Kaiserreich had of the British, French, and American Empires while Schmitt was growing to maturity.
\end{abstract}

\section{INTRODUCTION}

Carl Schmitt's writings on international law during and immediately after the Third Reich will be taken here as a heuristic device to introduce a number of issues to do with international law in the Third Reich. Perhaps the most important, of continuing interest, is whether Schmitt's critique of political (and legal) liberalism, if carried over into international law, had the effect of undermining the integrity of the discipline. This is because Schmitt's critique of liberalism enjoys at present considerable interest outside of Germany.1 The central feature of liberalism is taken here to be

\footnotetext{
* Professor, Faculty of Humanities, Languages \& Law, University of Derby, United Kingdom.

1. See G.L. Ulmen, American Imperialism and International Law - Carl Schmitt and the US in World Affairs, 72 Telos 43 (1987). Telos continues to render a service in explaining Schmitt's views on international law in the period considered by this article. See, in particular, 109 Telos 54-109 (1996), for a translation of Chapter II of Schmitt's 1950 publication Nomos der Erde, titled The Land Appropriation (translations by G. Ulmen and K. Walker); C. Schmitt, Der Nomos der Erde im Völkerrecht des Jus Publicum Europaeum (1950). See also, in the same issue, the review of another book by Schmitt: H. Quaritsch, Carl Scmitt's Das International-rechtliche Verbrechen des Angriffskrieges unter der Grundsatz "Nullum Crimen Nulla Poena Sine Lege,” 109 Telos (1996).
}

[end of page 25]

the view that a legal order has effectively devised general rules or norms that determine clearly the relationship of the freedom of individual legal subjects to one another.

Critical legal theorists fiercely criticize this paradigm for international law. They regard liberalism as ambiguous about the relationship of individual legal actors to one another. They say that claims of individuals 
conflict and that liberalism, for better or for worse, excludes any concept of authority standing over individuals which could resolve these conflicts.2 Schmitt appears to reduce all law to the capacity of a would-be sovereign to judge a state of emergency or exception. 3 A question, for a historian of international law, is whether Schmitt applied his 'antinomianism' systematically to international law and whether the critical international law theorist then finds himself in 'strange company.'

The response which will be given here as to the place of Schmitt's critique of liberalism in his international law theory is that, with considerable but not decisive reservations, he did introduce a fundamental feature of Nazi thinking into international law, that of a Weltanschauung. He insisted that instead of a global, if formal, world order, governed by abstract, in the sense of not person or subject-oriented, legal norms, world society be divided, as also national society, among those who share subjectively held 'world views.' These are value-systems which explain for themselves how to give sense to lives but which cannot be translated into opposing 'world views' and which therefore necessitate a radical relativisation of the international order. These concepts of world order are, of course, liberalism, national socialism, and communism/bolshevism. 4 The least clear of these concepts is national socialism itself. Schmitt's work has to be understood as part of a struggle within the Nazi regime to determine the meaning of the regime's ideology. The continuing challenge of Schmitt's theory is precisely that highlighted by critical theory.

If Law is really a subjectively held Weltanschauung then the elimination of the Weltanschauungen opposed to liberalism still does nothing to strengthen the epistemological credibility of the latter. The international legal order still rests upon subjectively held assumptions about the individual in society. Those who hold such assumptions effectively coerce

2. A review of this literature is offered in A. Carty, Critical International Law: Recent Trends in the Theory of International Law, 2 European JIL 66 (1991). In my view this literature comes from within the liberal tradition and lacks any historical sense. See further, A. Carty, Liberalism's Dangerous Supplements: Medieval Ghosts of International Law, 13 Michigan JIL 161 (1991).

3. The intention is to come back to Schmitt's general theory of law in a second, critical part of this study. In the first part there will be merely an excursus made at a number of points where this is thought essential to an understanding of the exposition of Schmitt's international law ideas.

4. A very well known contemporary typology of international law in terms of the differing Weltanschauungen is the product of a seminar at the Frankfurt Law Faculty in 1938: see F. Giese \& E. Menzel (Eds.), Vom deutschen Völkerrechtsdenken der Gegenwart (German International Law Thinking at Present), at 52-143 (1938).

[end of page 26]

others to accept them in the same way as any group asserts an ideological hegemonic dominance.s This is quite a different interpretation of the universal legal order than the self-representation of legal liberalism. At present it is probably the case that apart from Arab and Islamic fundamentalism, the only challenge to legal liberalism is from the very weak

Law and Development movement, which tries to object to the effects on the less developed world of the liberalization of the world economy.6 This is still an appropriate level at which to object to liberalism. However, to anticipate Carl Schmitt's arguments about Grossraumordnung (order of a large space), there is no major Power which defends the developmentalist ideology. Given the present world dominance of legal liberalism in international society, it is of considerable value to understand precisely what was defeated with the extinction not merely of the Third Reich, but also of its 'international law tradition.'

If one were only to consider the impact of his work on the

Grossraumordnung, one might claim that Schmitt was the most renowned 
international lawyer of the Third Reich. It has to be said that, at least within Germany, if one is to write of Carl Schmitt, one will be expected to be either for or against him. In the field of international legal study one can say that professional German international lawyers do not accept the study of Schmitt as a respectable topic of study. The one major study of his work is by a legal historian.7 It represents a courageous attempt to establish important principles of scholarship for the study of Schmitt as an international lawyer in the period of the Third Reich but it does not purport to argue, as will be done here, that Schmitt's work is very useful for an understanding of the development of the international law discipline as a whole.

One has to be realistic that this raises, at least in Germany, the question of where does the author 'stand' in relation to Carl Schmitt? The response has several aspects.

Perhaps the most important is that Schmittian national socialist critique of international law provides an indispensable historical perspective for an understanding of the liberal international legal order. This is meant in the sense that the discomfort that Schmitt arouses makes it possible to treat him, virtually standing on his own, as the shadow side of the post-war (1945) international law of peace, human rights, and democracy in the

5. This is appreciated in the excellent article by Ulmen (American Imperialism), supra note 1. Ulmen considers Schmitt from a general perspective of critical theory (in the sense of ideological critique), including Schmitt's post-World War II writings. The aim is to see what light this throws on American perspectives. The present study has the more limited aim to approach Schmitt's work from an international law perspective, especially with respect to the nature and political implications of Schmitt's Nazi associations. 6. See, e.g., A. Carty, Liberal Economic Rhetoric as an Obstacle to the Democratization of the World Economy, 98 Ethics 742 (1988); and A. Carty, Third World Claims to Economic Self-determination: Economic Rights of Peoples, Theoretical Aspects, in P. de Waart \& E. Denters (Eds.), The Right to Development in International Law 43 (1992).

7. M. Schmoeckel, Die Grossraumtheorie (1994).

[end of page 27]

Western world.8 This is, at least, because he did not recant from the positions that he held during the Third Reich, except in his personal estimation of Hitler. He refused to be denazified. As such Schmitt serves as a focal point for the numerous other German international lawyers who did recant, or simply changed their song, after 1945.9

The question then arises: what kind of legal history is being written here? Is it an attempt to explain how Nazi international law was possible? Is it an attempt to expose the extent to which, despite appearances, the Nazi doctrine and practice have influenced international law today? Is it an attempt to read into the defeat of Nazi international law an onward march into a global victory for a liberal concept of international law? Is it a purported objective analysis of what Schmitt really meant in the context in which he lived?

My view is that it is not possible to look at the past quite apart from the demands of the present. The historian, legal historian, or whatever, is not some kind of disembodied spirit who can look at the past apart from where he is himself.10I have endeavored to explain the perspective from which I approach this subject. It is a mixture of dissatisfaction with present international law, from a critical legal standpoint, a respect for the technical competence of Carl Schmitt as an international lawyer, a determination to try grasp at what it was like to write international law in Hitler's Germany, and a decision to explore a subject because it has made resistance to liberalism so much more difficult. 


\section{Carl Schmitt's Writings on International LaW During the NaZi Regime}

\subsection{Introduction}

I will limit my scope largely to Schmitt's writings during the period of the Third Reich. To some extent there will be mention of post-1945 comments by Schmitt on his writings, but the technical limitations of

8. The 'shadow' is also a favourite theme of the deconstructive wing of critical legal studies: see, e.g., P. Fitzpatrick, The Abstract and Brief Chronicles of the Time: Supplementary Jurisprudence, in P. Fitzpatrick (Ed.), Dangerous Supplements, at 1 (1991).

9. See the very comprehensive survey of this phenomenon by D.F. Vagts, International Law in the Third Reich, 84 American JIL 661 (1990); see also M. Messerschmidt, Revision, Neue Ordnung, Krieg, Akzente der Völkerrechtswissenschaft in Deutschland 1933-45 (Revision, New Order, War and Trends in the Science of International Law in Germany 1933-1945), Militärgeschichtliche Mitteilungen 61 (1971). Here numerous names of prominent German and Austrian international lawyers appear, such as Menzel, co-author of an already cited work from 1938, Verdross, Berber, Dahm, and Scheuner.

10. All of these possibilities are canvassed thoroughly by M. Stolleis, Recht im Unrecht (1994), 36 at 54-55 (Vorurteile und Werturteile der Rechtshistorischen Forschung zum

Nationalsozialismus). Stolleis himself prefers the last option of those mentioned above.

[end of page 28]

writing an article and not a book mean even here that the choice of a limited number of post-1945 writings will appear arbitrary. The essential interest remains in how did Schmitt write international law during the time of the Regime? A further limitation that is self-imposed is that I am not specifically interested in Schmitt's opposition to the Versailles Treaty.11 Obviously many of these texts appear after 1933 . They are clearly related to the subject, if only because the resentment against the Treaty must have determined Schmitt's sympathy for the Nazis. However, within this short study, I wish to see how far he developed a specifically Nazi concept of international law in response to this undoubted resentment.12 Finally, I am not attempting here a review of Schmitt's liberalism critique.13 What I have to say is relevant to this critique, but is not limited to it. I approach the topic with a specific international law interest, which is that National Socialism has, at least as much as Soviet communism, made any serious resistance to the liberal conception of international law virtually impossible. I have no interest to playing down Schmitt's association with the Regime. With all of these qualifications, I am in absolutely no doubt that Schmitt's international law writings are quite simply good, and merit careful exposition without an overload of afterthought.

Hence the first part of this paper attempts to set out his views. There is only contextual elaboration, in the form of an excursus, wherever this is thought absolutely essential for an international lawyer to understand what Schmitt is saying. The criticism that I have to make comes in the second section.

The assumption in the already existing critical literature is that there were from 1933 definite stages in the history of National Socialist international law doctrine during the Third Reich. In particular Schmoeckel writes that it has become usual to distinguish Nazi international law writing into three periods:

1. 1933-1935, where a natural law doctrine of basic rights prevailed;

11. His writings on this topic are collected in C. Schmitt, Positionen und Begriffe im Kampf mit Weimar - Genf - Versailles 1923-1939 (Positions and Concepts in the Struggle with Weimar, Genf, Versailles 1923-1939) (1988).

12. In conversation with the author, Günter Maschke has contended that crucial to an understanding of Schmitt is his (Schmitt's) mistaken assumption that Germany had no choice but to sign the Versailles Treaty. The outcome was inevitably a self-hatred, the result of a self-imposed humiliation. 
13. See K. Hansen \& H. Lietzmann (Eds.), Carl Schmitt und die Liberalismuskritik (1988), esp. G. Maschke, Drei Motive im Anti-Liberalismus Carl Schmitt, at 69-73. Maschke considers Schmitt's foreign affairs and international law writing exclusively from the perspective of his Weimar anti-liberalism, without any reference to his adherence to Nazi ideology. The same is true of his Forward to his recently edited collection of Schmitt writings: See G. Maschke (Ed.), C. Schmitt: Staat, Grossraum, Nomos, at xiii-xxvii (1995). Maschke confines himself to distinguishing Schmitt from other Nazi writers without directly addressing Schmitt's clear support for the Nazi Regime as such as an effective response to anglo-american universalism.

[end of page 29]

2. 1936-1939, where a racist doctrine came first; and

3. 1939-1945, where a theory of Grossraum had the centre stage.14

This has the merit that it corresponds to three phases in Nazi foreign policy: the winning back of full sovereignty, the policy of establishing national ethnic boundaries, and the Grossraum period.15 I do not follow this scheme because my main interest is to explore Schmitt's own attachment to Nazi ideology, which appears to have been immediate. Furthermore, his work on the Grossraum (Völkerrechtliche Grossraumordnung) will be considered before his work on the concept of war (Die Wendung zum discriminierenden Kriegsbegriff) (the turn to a discriminating concept of war), although it comes after it chronologically and was presented as a completion of it, i.e. Schmitt's alternative to the English and French call, which Schmitt criticizes, for international institutions as the way forward in the development of international law. The reason for this non-chronological ordering of Schmitt's work is that, approaching it as an international lawyer, I see it as preferable in systematic terms to consider his vision of a National Socialist international order before I approach in detail the opposition which he expected it to arouse. It appears to me that there is more premonition of coming war in his discussion of the concept of war than in his discussion of the concept of Grossraum. So, the Wendung zum discriminierenden Kriegsbegriff leads more logically to a discussion of his specifically wartime texts. Another crucial international law text, Der Nomos der Erde (the nomos of the earth) was written during World War II, although published in 1950. It will only be considered here in one respect, the collapse of the idea of a European international law. The reason for this is not a matter of space. I would simply accept that by the time of finishing the book Schmitt had given up interest in developing a specifically National Socialist concept of international law. The part of the book I consider is nonetheless presented because it gives a picture of the mess in which Schmitt thinks liberalism leaves international law, notwithstanding the failure of National Socialism.

\subsection{National Socialist Weltanschauung and international law}

\subsubsection{Excursus $I$}

The concept of Weltanschauung is so closely associated with National Socialism as to be now discredited. However, it is worth noting that Karl Jaspers, himself an exile from the Regime, devoted an early major study to the topic. This is not to say that one can simply jump from Jaspers to Schmitt. However, Jaspers does provide a starting point for an epistemo- 
logical consideration of Schmitt's theories by explaining how they resemble subjectivist tendencies deep in the history of German thought. Jaspers places his considerations within the context of his eventual development of an existential (also subjectivist) philosophy. The concept,

Weltanschauung, belongs firmly within German idealism. This tradition's founder, Immanuel Kant, is held by Jaspers as originally responsible for the doctrine that ideas have a subjective character.16 Fichte and Nietzsche who both see a philosophy as a personal creed (Selbstbekenntnis) of its originator accentuate this subjectivity. The type of philosophy a man chooses shows what he is for a man, says Fichte. ${ }_{17}$ Given the great confusion of so-called philosophical systems at the time of writing in 1919, Jaspers endeavors to unravel what associations of ideas most genuinely express the totality of individual perspectives. This means giving priority to those ideas which are really held, and which represent a total vision of the subject. This is not to say that everyone really holds such perspectives, but the philosophy which is evolving towards existentialism looks first to distinguish what is held as a matter of conviction from what is held casually and, second, to what serves to distinguish a firm personality from one which allows itself to be dispersed in different directions. 18 It is obvious that such a type of intellectual inquiry makes a direct connection between the person and the subject matter and has built into it an inquisitorial function. A psychological approach will always look with distrust behind the subject matter to the person. 19 It is hardly an accident that discussions about Weltanschauungen prove to be acrimonious, as has already been hinted at in the Introduction.

In 1934 Schmitt published an article called Nationalsozialismus und Völkerrecht, which is presented as a lecture which he gave on 18th July 1934. The Party formally printed that it had no reservations about anything in the text.20 Schmitt begins his lecture by insisting upon the importance of the subjective dimension for international law. It is the inner form/type of a People (Volk), which is the basis and precondition for the character of inter-state relations. When a People as essential to the international law community as the German People change their form/type, this must have serious implications for the international legal community.21 Schmitt begins his attack on liberalism at once with an insistence upon the insights that can be won from the new National Socialist perceptions of the German People. The type (Art) of a community depends upon the type of its

16. K. Jaspers, Psychologie der Weltanschauungen, at 12 (1919), referring also to an Appendix titled Kants Ideenlehre (Kant's Doctrine of ideas), at 465-486.

17. Id., at 38 .

18. Id., at 35-37.

19. Id., at 38 .

20. C. Schmitt, Nationalsozialismus und Völkerrecht (1934).

21. Id., at 1 .

[end of page 31]

members. The connection between international law and Weltanschauung is made exactly as one might expect from Jaspers:

So it follows that the Law of inter-state relations and associations does not develop from abstract-normativist, rule-oriented thinking, but rather from a concrete Order of a particular kind, which has evolved its particular character from certain states and peoples $[\ldots] .22$

It is to the Nazi Movement (Bewegung) that one owes the realization that Law rests upon a 'substanzhaften Ordnungsdenken' (substantive thinking about order). Law is a matter of a correct relationship with the concrete existence of a People. There is no separation of the juridical Norm from the People's right to life (völkisches Lebensrecht).23 
Schmitt proceeds to identify the post-1918 (Versailler Diktat) international law as arising from a liberal, positivist, and therefore abstract-normativist, rule-oriented Weltanschauung. This goes back to the 19th century and has coercion (Zwang) as its central feature. Law is a matter of procedures that compel observance of norms. In terms of international law this perspective means some states take it upon themselves to compel observance of norms by other states. The 'Vienna School' of international law has perfected this theory so as to hide the fact that some states are coercing others. It means that rules, somehow above states, can be imposed down upon them, a normative system that imposes itself, apparently impartially, but in fact hierarchically in opposition to the concrete order of existing Peoples. So, in Schmitt's view the liberal Vienna School fits perfectly alongside the imperialism of the Versailles Treaty regime. So the role of Weltanschauung is decisive. The system which Germany finds oppressive can be explained "entirely and exclusively in terms of the command of a particular, holy Weltanschauung of Versailles Imperialism, with its pacifist and liberal-democratic political way of thinking [...]." 24 It can be said, in Schmitt's view, that German international legal science has fallen into the same way of thinking. It cannot be said, with very few exceptions,

[t]hat the entire German science of international law has shown an unwavering legal conviction, with the certainty of self-assurance, in a genuine spiritual self-defense, as has [the legal science of] other smaller peoples, such as the Hungarians

$[\ldots] .25$

There are at least three important respects in which Schmitt carries forward his lecture. At the same time as outlining its logical coherence, it is important not to lose sight of the rhetorical force and propaganda inten-

22. Id. (all translations are the author's).

23. Id., at 7 .

$24 \mathrm{Id}$.

25. Id., at 11 .

[end of page 32]

tion of the lecture. Schmitt argues convincingly that the whole normative structure of international law, based upon treaties, is emptied of content because of the reservations which states make. He refers in particular to the Geneva (Draft) Protocol, the Locarno Agreement and the KelloggBriand Pact. These reservations by states express a return of the hard and repressed fact that Law can only be based on the concrete lives of states.26 An aspect of this inevitable subjectivity, where states decide themselves in practice whether their very existence is threatened, is that more powerful states can subvert the so-called normative, treaty based, order to determine that their weaker opponents are aggressors or delinquents. This is a legalization of war, a dressing up of aggressive action as peacekeeping measures.27

Schmitt's intention is to show the ever-weakening legitimacy of the League. So, even if it could be said that at the beginning the League of Nations had some 'Soul' as expressing Wilson's liberal democratic and humanitarian ideology, this is lost when a bolshevist state such as the Soviet Union and fascist Italy, not to mention the eastern European regimes, are together in the League. The latter then becomes an opportunist alliance and "no longer a genuine community [...]." ${ }_{28}$ Schmitt takes away the legitimacy of the League, weakening the Versailles system, by denying that it serves universal values in practice. At the same time, he says that Germany should not allow itself to be tricked into appearing as an outlaw state, which denies the binding character of a universal international law and treats the sovereign state as superior to international 
law. Germany objects instead, at a technical level, to the mistaken liberal perspective that Law has to be a coercive system with organs capable of enforcing rules against recalcitrant parties, with sanctions, especially where the British and the French dominated League will provide the organs to carry out these sanctions.29

At the same time Schmitt calls for a rejection of the positivist Geist (Spirit) of 19th century international law doctrine, i.e. of Kaiserreich Germany. To preach a doctrine of unlimited state sovereignty will only inspire suspicion among Germany's neighbors at a time when (1933-34) Germany is the weaker party. It is Germany that is likely to suffer the more from such lawlessness implicit in a return to the legal theory of the jurist of the pre-war period, such as Zorn.30 This rhetorical style of hurt innocence builds up its own momentum when Schmitt protests additionally against the model of relations of the Soviet Union with the West in the years after 1917 as a model for Germany. That would stress absolute state sovereignty so as to loosen ties with other countries.

26. Id., at $23-25$.

27. Id., at 21 .

28. Id., at 25-28.

29. This is a comment on a work generally criticised by the Nazis, namely L. Schecher, Deutsches Aussenstaatsrecht (German External Public Law) (1933); id., at 15.

30. Schmitt is following the official line. See Bristler, supra note 14, at 63-71.

[end of page 33]

We belong to the legal community of European peoples [...]. We cannot be excluded or excommunicated from the community of European peoples[...]. Whoever will excommunicate the German people, excommunicates only himself $[\ldots] .31$

Despite the firm appeal to an National Socialist Weltanschauung which calls for international law to be grounded in the existential, echte Lebensrechte of Peoples (genuine living rights), the content which Schmitt gives this Law is an appeal to the traditional pre-1914 doctrine of the basic rights of states, their Grundrechte, above all, of course, the right of self-defense, and the right of an equal capacity for self-defense. $32 \mathrm{He}$ recognizes that doctrinally there is nothing original here. He appeals to a well-recognized international law tradition. 33

This fact raises acutely the question whether the whole so-called dimension of a Weltanschauung is purely rhetorical. This can be answered only when Schmitt's theories of international law have been comprehensively reviewed. Here, the preliminary point will be noted that the reference to Grundrechte of states is an appeal to a pre-1914 liberal tradition of international law, to pre-institutional (effectively pre-League of Nations) rights which were accorded by liberal legal theory to states as in a virtual state of nature and as an expression of their natural freedom. It will stress the relativist aspect of the philosophy of Weltanschauung that Schmitt holds to. Also the predominance of the doctrine of basic state rights will be an indication of the preoccupations of one particular state as the 1930s unfold. All of this corresponds to dominant and representative National Socialist international law doctrine. 34

\subsection{Völkerrechtliche Grossraumordnung}

There are numerous further occasions where Schmitt develops his attack on the League of Nations. 35 However, these negative criticisms of the lack of homogeneity in international institutions should give way to the, as it were, positive vision of an international order that Schmitt offers. This 
vision is derived from his Nazi theory of the nature of Law. The key text, Völkerrechtliche Grossraumordnung, also begins with the insistence that international law is a personal law, a Law of Peoples (Recht der Völker). It is a 'konkrete Ordnung' which depends on the fundamental

'Ordnungsprinzip,' the principle of the self-determination of peoples (Das

31. Schmitt (Nationalsozialismus und Völkerrecht), supra note 20, at 17.

32. Id., at 8 .

33. "For us it is now a matter of returning to this pure source of international law thinking recognised by all sound international lawyers in the past [...]." Id.

34. Bristler, supra note 14, at 71-108.

35. See, in particular, C. Schmitt, Die siebente Wandlung des Genfer Völkerbund, in Schmitt (Positionen und Begriffe), supra note 11, at 210-213.

[end of page 34]

Selbstbestimmungsrecht der Völker). 36 Schmitt opposes not only the concept of People to State but also contrasts a 'konkreten Grossraum' to a 'konkrete Raumordnung' (concrete order of space). It will be necessary to refer back to Schmitt's earlier writing, in 1934, on the concept of 'Konkretesordnungsdenken' (concrete order thinking). However, it is better first to introduce clearly how this latter concept appears in his international law thinking.

Schmitt begins by repeating his view that there is no concept of Raum (Space) in international law because it is dominated by what he calls a Vertragspositivismus (treaty positivism), which is the equivalent of the Gesetzpositivismus (legislative positivism) of liberalism at the domestic level of the state. He does not elaborate here in further detail on this concept. So another Excursus will be necessary.

\subsubsection{Excursus II}

In the 1920s Schmitt elaborated fully his criticism of legal normativism as applied to state and law. The starting point is the significance of such expressions as "governance of Laws not men," government "in the name of the Law," and "equality before the Law." ${ }_{37}$ It is bound intimately with the victory of the European liberal middle classes, particularly after 1848, with the central place for parliamentarianism.38 The legislation approved after free and intelligent discussion in Parliament should have a general, abstract character but, at the same time, should be sufficiently clear and definite to allow of fairly automatic application without recourse to excessive judicial or executive discretion. This legal-political history is the origin of the normative approach to Law. All that one needs to add is the coercive element. The Law in this sense of Loi or Gesetz does need to be backed by a sanction which can be all the more automatic in that it should be pretty clear when there have been violations of the Law.

Effectiveness of the norm/Law means that such sanctions follow regularly in the event of violations.

The implications of this approach to Law for international law hardly require a paragraph. Legislation is a product of the will of Parliament. The fundamental source of such Law-making at the international level can be described as the will of the State. The primary source of international law now becomes treaties that are intended to function as law-making conventions.

States express their wills in law-making conferences, intending not merely to conclude treaties as commercial or political bargains but also

36. C. Schmitt, Völkerrechtliche Grossraumordnung, mit Interventionsverbot für raumfremde Mächte (International law of the Greater Space, with a Prohibition of Intervention for Powers Foreign to the Space), at 7 (1997).

37. See, e.g., C. Schmitt, Legalität und Legitimität (1932), included in C. Schmitt, 
Verfassungsrechtliche Aufsätze (Constitutional Law Essays) 263 (1958), at 264 et seq.

38. C. Schmitt, Die geistige Lage des heutigen Parlamentarismus (The Intellectual Situation of

Contemporary Parliamentarianism), at 10 (1923).

[end of page 35]

to edict general rules of conduct for the international community.

Inevitably, it will be supposed that since Law requires a sanction at a national level some kind of international substitute for a sanction can either be found or be supposed to exist.

Schmitt clearly presents his opposition to Gesetz/Vertragspositivismus in the strongest possible Nazi terms. Positivism's abstract lack of attachment to place, or to any natural relationship to concrete ground, and its willingness to construct an international legal order which consists of equally abstract delimitations of competence, is all particularly attributable to Jewish influence. It is a particular characteristic of Jewish existence that any 'natural relationship with concrete Land/ground' is missing. Kelsen and others are held responsible for having transformed the concept of state territory (in their definition of the state in international law) from being the ground for a settled People (dem Boden eines sesshaften Volkes), into nothing other than the simple sphere of competence of a legal order. 39 This criticism is no accidental part of Schmitt's thinking. It repeats the themes of the seminar which he organized in 1936, Das Judentum in der Rechtswissenschaft ('Jewishness' in legal science) and, in particular, the contribution of Norbert Guerke on the influence of Jewish theorists, especially Kelsen, on international law.40 Schmitt stresses as well the role of the work of Walter Hamel in providing the most thorough theoretical resistance to this emptying of the concept of territory.41 Schmitt has to stress this aspect of his theory of international law, if it is to be possible to insist on a non-universalist concept to oppose to liberal Vertragspositivismus.

Schmitt is going to differentiate his position from colonial-imperialist arguments about international law and land, which might argue, for instance, that more heavily populated areas may have territorial claims on less populated areas. A demographic claim may have a basis as a legal claim, but it cannot provide a specific foundation for a konkretes völkerrechtliches Grossraumprinzip which by itself, essential to the character of Konkretesrechtsdenken, can provide its own clear limits and standards.42 Schmitt consistently rejects a geopolitical concept of Grossraum, as argued by Karl Haushofer, in favor of an argument which links space and a political idea. This idea will have a People as its standard-bearer. For it to be a political idea, the People carrying it must find themselves in opposition to another idea. Here Schmitt insists, again, upon the relevance of his understanding of the concept of the Political, which

39. Schmitt (Völkerrechtliche Grossraumordnung), supra note 36, at 12-13.

40. See the discussion of this seminar and references therein in A. Carty, Interwar German Theories of International Law, 16 Cardozo LR 1235 (1995), esp. at 1245-1251.

41. Schmitt (Völkerrechtliche Grossraumordnung), supra note 36, at 13, referring to W. Hamel, Das Wesen des Staatsgebiets (The Nature of State Territory) (1933).

42. Id., at $15-16$.

[end of page 36]

supposes ideas in opposition. His concept of Grossraum is tied to a triad of Land, People, and Idea that he opposes to liberal universalism. 43 Recalling the opposition of the American Monroe Doctrine to the Holy Alliance of Prussia, Russia, and Austria at the beginning of the 19th century, Schmitt now insists, in the spirit of struggle and conflict which is central to his concept of the Political, that the position of the expansionist 
Holy Alliance is now occupied by the 'liberal idea of freedom of the western democracies.' It represents a commitment to the legality of the status quo, and gives to actual world possessions the sanctity of the principle of Legality, as well as of Legitimacy. These principles have shaped the international order throughout the waging of the World War I, and represented a determination by Western powers to impose globally their democratic parliamentarian ideology, making a complete connection between the external and internal affairs of states. The war was a form of intervention, in which the Western powers treated as central to their aims, the imposition of their form of government on enemy powers. This is the context in which Schmitt thinks it necessary to develop a theory of nonintervention in connection with a new German-style Monroe Doctrine.44

Far from wishing to adopt or to imitate the Monroe Doctrine, Schmitt is conscious that it has now become historically obsolete. Since at least the time of Theodore Roosevelt, the United States has abandoned its concrete, geographically, and historically located theory of Grossraum, in favor of a general, universalistically conceived World Principle. This latter has a clear economic function that is the imperialism of 'dollar diplomacy.' Imperialism and capitalism go together. With President Wilson, by 1917 a sound (because concrete and spatially definite) Ordnungsdenken has been dissolved into an expansionist, economic imperialist universalist 'world-Idea,' which is taken to justify an unlimited authority for intervention. 45

\subsubsection{Excursus III}

This is the point at which it is felt appropriate to introduce Schmitt's concept of Konkretesordnungsdenken and to explain how it is seen as opposed to the liberal concept of normative, rule-based legality. Schmitt needs to link his Grossraum theory to this theory of Law because, somehow, the theory has to indicate how it will accept limits upon itself, required by space and people. How is this so? At present the intention is merely to provide the minimum of explanation of Schmitt's ideas so as to understand better how he develops his international law theory. The question how far Schmitt could impose such ideas on Nazi orthodoxy will have to be treated more thoroughly at a latter stage.

43. Id., at 32-34.

44. Id., at 36

45. Id., at 36-39.

[end of page 37]

Once again Schmitt opposes Jewish and Germanic thinking. There are peoples without land or state or church who exist only for the Law, for normativist thinking. There are others, such as medieval Germans, for whom a concrete order is more attractive. This accommodation of typical NS thinking includes the usual party line that the reception of Roman Law, from the 15th century, worked in favor of abstract normativism. ${ }_{46}$ Schmitt is clearly opposing himself to what he has consistently regarded as a fetishism of Law. Law cannot simply define, apply or interpret itself. The idea of Law, Nomos, supposes a concrete order and a concrete community. He quotes Hoelderlin at length that the Nomos is the figure in which Man finds himself in his own presence and meets God; and the Law of the State, including the statutes inherited for a long time, conserves, with more rigor than Art, the living conditions in which a people finds itself. 47 There is no doubt that Schmitt sees a link between this thinking and medieval Germany, where Aristotelean-Thomist thinking understood the world as a series of hierarchies of essences and orders, a way of thinking which has 
survived in Germany.48 He connects this tradition with Luther who also saw Law as arising from the status people enjoyed as a mother, judge, soldier etc.,49 until one reaches the general status of the German People. The Germans as a People are the focus of the concerns of its philosophers since the beginning of German idealism. The objective idealism of Hegel is Konkretesordnungsdenken, while Fichte understood the notion of Reich as the most German concept of order. Schelling perfected this by linking the cosmic concepts of organism, Weltanschauung, and myth, all drawn back to the spirit of the German People, to remind them of their dignity and their own strength in the face of foreign invasion. The final Summa of this thinking is Hegel's Philosophy of Right.50 With the decay of the Holy Roman Empire Hegel transferred to his concept of the Prussian state the idea that this state is an Empire (Reich) of the ethical life and of Objective Reason, capable of sustaining itself above civil-bourgeois society. The latter taken alone would lead to the functionalism of legal normativism which has to make its rules respected through force. The Hegelian state is not a positivist, decisionist, or dictatorial entity, but the Order of Orders, the Institution of Institutions.51 There is an important development of this 'Hegelianism' which is supposed to explain how National Socialism makes up the defects of the Hegelian state which has lost its way with the abdication of the Monarchy and the subsequent lack of direction of the Prussian Army and the State bureaucracy. ${ }_{52}$ Here it is

46. C. Schmitt, Les trois types de pensée juridique, at 69 (1995).

47. Id., at 74-75.

48. Id., at 93-94.

49. Id., at 95 .

50. Id., at 97 .

51. Id., at 97-98.

52. Id., 101-102, 112. See also C. Schmitt, Staat, Bewegung, Volk, Die Dreigliederung der politischen Einheit (State, Movement, People: The Three elements of Political Unity) (1933).

[end of page 38]

enough to stress that for Schmitt Law arises from the concrete reality of the conditions of life, which means, for this rather abstract language, the state community, the social community and, above all, the völkische community. 53

Quite simply, Konkretesordnungsdenken will mean for Schmitt a defensive German resistance to perceived, above all, cultural imperialism from the Anglo-American world. So he begins a new section of the study with such rhetoric as "[u]niversalist, all-embracing global and general concepts are in international law the typical weapons of interventionism." ${ }_{54}$ Indeed Schmitt also attributes a British tendency to universalist juridical thinking to the dispersed nature of British territories and the absence of any definite central location. Hence British arguments for the security of communications would have a universal quality, i.e. not geographically located. At this point Schmitt recalls his basic thesis in Nationalsozialismus und Völkerrecht, that international law is a law of treaty reservations and that, rather than construct a special legal theory for the seaways, Britain makes reservations. For example, the 1922 Treaty with Egypt allowed reservations to secure, inter alia, the rights of minorities and the security of passage. The Suez Canal is presented as a universal means of communication whereas, of course, Britain is representing its own interest in universal terms.

The approach of Britain to the Kellogg-Briand Pact is similar. As with the Monroe Doctrine, it is stated that certain territories of the world are of vital (lebenswichtige) interest for Britain, that any interference in these territories will not be tolerated and a reaction will be regarded as an act 
of self-defense. 55 In this way Schmitt demonstrates quite clearly how legal arguments can always be reduced to expressions of interest determined by space, location etc., so that it is only reasonable for each significant Power to think through what its own space-determined, self-understanding is. This close relationship between geography, state interest, and the development of legal thought can be seen in the British and Dutch defense of the freedom of the High Seas against Spanish and Portuguese claims to monopoly. Schmitt does not dismiss this way of thinking as cant or hypocrisy. Epistemologically he sees it as inevitable that legal Weltanschauungen are shaped by what are simply personal, existential factors, i.e. attaching to individual subjects of a legal order. It is, for Schmitt, an example of the unavoidable attribution of a certain international law way of thinking to a particular type of political existence. The alternatives for international society are echte Grossraumprinzipien with a rule of non-intervention or a false Grossraumprinzip with a consequently limitless practice of intervention. 56

53. Schmitt (Pensée juridique), supra note 46, at 110-111.

54. Schmitt (Völkerrechtliche Grossraumordnung), supra note 36, at 43.

55. Id., at 44-48.

56. Id., at 52-54.

[end of page 39]

Returning to the theme that the international stage is dominated by the struggle of individual Powers to impose their own internal political constitutions on others, Schmitt opposes the liberal-democratic concept of the defense of minorities to the concept of the Volk and Volksgruppe. The contribution of German legal thinking has been to oppose a doctrine of minority rights, which is confined to the protection of the individual against discrimination because he is a member of a group. Instead, one has to recognize there is no particular concept of minority but merely "different types of living communities [...]." ${ }_{57}$ For liberal democratic states there can be no place for protection of minorities because all individual rights can be guaranteed by the freedoms and rights of a constitutional state. This is a structural link between national constitution and international ${ }_{58}$ legal hegemony, in reality a drive to globally enforced homogeneity. To resist this in a European Ostraum (eastern space) requires the recognition of a different concept of People. Germany has developed such a concept. Here, Schmitt places himself firmly within the strains of German thought which insist upon the priority of group over individual identity and which use the language of race. In particular he relies upon the work of one of the foremost National Socialist theorists, Walz.59 This leads him to assign to Germany a special role in resisting the ideological hegemony of liberal democracy, as enshrined in the minority rights system of the Versailles Treaty. There has to be a defense of the 'volkshaften Eigenart jeder Volksgruppe' (national particularity of each ethnic group) against western assimilation, and it has to be by Germany, the particular state power whose People are present in this Space, the German Reich. Adolph Hitler stated the principle in a speech to the Reichstag on 20 February 1938 , as a right of protection of Germans in other countries. This itself is part of the basic principle of mutual respect of each 'Volkstum,' which underlies the German-Polish declaration of 5 November 1937, itself denying any attempt to assimilate and absorb different Volksgruppen.60 Words such as particularity and type refer to race. It is this racial concept of the Volk that Schmitt calls the political idea which should inform the new Grossraum of the Middle and East European Space, where there is a respect for different Peoples, apart from the Jews. There is a space in which 
Peoples which are not of a different kind live, i.e. except for the Jews who, supposedly, are different. It is not a matter of a German Monroe Doctrine, but a development of a similar thinking to the early stages of the Monroe Doctrine, adding to it the special right to protect German minorities.61 In

57. Id., at 59 .

58. Id., at 60.

59. Id., citing G.A. Walz, Artgleichheit gegen Gleichartigkeit. Die Beiden Grundprobleme des Rechts (Similarity of Type Against Equality of Type: The Two Basic Problems of Law) (1938).

60. Schmitt (Völkerrechtliche Grossraumordnung), supra note 36, at 63-64.

61. Id., at 64-65.

[end of page 40]

the context of this section of the text, Schmitt's argument reads as a determination to place Germany, in relation to Eastern Europe, in the place in which Clemenceau had hoped France would enjoy under the Treaty System generally, and under the Minority Treaty System.62 Schmitt sees the development of the concept of Grossraum in terms of imperial rivalries in which Germany has more understanding of the nature of Volksgruppen in eastern Europe and can, on the basis of mutual respect of these groups, ensure the exclusion of Western liberal-democratic Powers, whose individualist state-constitutions mean they cannot understand this area of Europe, but which will, nonetheless, endeavor to impose their Weltanschauung as far as possible.

In this work, as generally with Schmitt, there is little attention paid to the Soviet side of the triad relative to the importance it had for Hitler and the Nazi Regime.63 Yet for him the boundaries of the Grossraum are clearly set in terms of Weltanschauung. On the one side there is the drive to assimilation with the goal of the melting pot and, on the other, there is the universalism of bolshevist-world revolution coming from the East. Against these forces, in a sharpest opposition, the German Reich has to defend in the middle of Europe between the two, the sacredness of a non-universal Living order that respects the differences of peoples. 64 The conclusion of Schmitt's argument covers rather too much ground too quickly. He refers to a widely held German and National Socialist view that the so-called international legal order of states, at least in Europe, depended upon a divided Germany and Italy.65 This was reaffirmed with Versailles. The renewed strength of the German Reich transforms this situation. This Reich is imbued with a so-called 'substanzhafter Volksbegriff.'

However, it would not be enough, as theoreticians such as Guerke propose, to replace an inter-state system with an inter-people system of international law. This would not be enough to resist universalist forces in world society. For this there is needed the concept of a Grossraum defended by a Reich. The concept of Reich is not developed enough in the text. However, Schmitt does stress that a Volk alone, without a state organization, will not have the organization and discipline necessary.66 As he sees the threat coming from the West, what is to be defended is still the idea of the Volk. Schmitt professes to have no doubt that the intention is already forming in the West to undertaken a so-called 'just war' against Germany.

62. Id., at 61 and 63 .

63. See again Giese \& Menzel (Völkerrechtsdenken der Gegenwart), supra note 4, at 114-143. 64. Id., at 71.

65. This was a fundamental feature of Nazi geopolitical-historical thinking about international law. See G.A. Walz, Völkerrechtsordnung und Nationalsozialismus, at 8 (1942).

66. Schmitt (Staat, Bewegung, Volk), supra note 52, at 32. None of this is to suggest that Schmitt distances himself from the Volk, as given shape by the Leader, in favour of a fascist Italian style state. The conditions for the latter did not exist any longer in Germany, hence the need for the Nazi Party etc. 
[end of page 41]

This is even being prepared in the academic literature.67 Therefore the extent of the threat means that the Volk alone is not enough to withstand it.

This does not mean that the object of the Grossraum ceases to be the Volk, but simply that much more is needed to compete with another Grossraum, which has expansionist, supposedly universalist aims. What Schmitt says is sparse. The Grossraum has to be defended by a Reich The idea of a Reich as an international law concept requires a Volk that has shown itself to be up to the task, and to be motivated by particular ideas and principles attaching to a Weltanschauung.68 The task of leadership falls to a specific Volk. It is difficult to see how Schmitt is anything but a 'main-stream' Nazi when he says that " $[t]$ he act of the Führer confers political reality, historical truth and a great international law future to our Reich." 69 The context of the so-called political Idea is once again a mutual respect of peoples in the full-blooded National Socialist sense of these words: "the respect for each People as a living reality determined by type and origin, blood and earth." ${ }_{70}$ Whatever may be noted later about supposed differences between statist and völkische approaches to Grossraumordnung, 71 it appears quite clear that Schmitt's acceptance of National Socialist racial ideology, in its most general form with respect to the principle of the self-determination of peoples, was wholehearted. The Grossraumordnung went through four editions between 1939 and 1941, the last appearing very shortly after the Nazi attack on the Soviet Union. The relationship between Schmitt's theories and Hitler's actual foreign policy will be explored in the second section of this study. At this stage, however, the intention is to follow the internal consistency of Schmitt's theories in the light of his reactions to events. This is essential to an understanding of the intellectual integrity of his work, which is not the same thing as the question whether Schmitt somehow hoped by his writings to ingratiate himself with the National Socialist regime.72

67. Id., esp. at 80-81. See also the key study of C. Schmitt, Die Wendung zum diskriminierenden Kriegsbegriff (1988), to be discussed in Section 2.4, infra.

68. Schmitt (Staat, Bewegung, Volk), supra note 52, at 86.

$69 \mathrm{Id}$.

70. Id., at 88 .

71. A basic thesis of Schmoekel's Grossraumtheorie is that Schmitt somehow ascribed to the former theory, for which he was criticised by more orthodox National Socialism theorists. See Schmoekel, supra note 7.

72. A methodological point which Schmoeckel also stresses is that the detail of Schmitt's work is too complex to allow a clear evaluation of the person at every stage. He deplores the general tendency to a biographical approach on the ground that it merely serves to strengthen already hardened positions of opposed camps in relation to Schmitt; see Schmoekel, supra note 7 , at 17 . While this comment may be true of contemporary German scholarship, it has to be asked, as a matter of the history both of ideas and of mentalities, how Schmitt came to hold an essentially racist, international law Weltanschauung, and to what extent he understood and accepted responsibility for how substantially similar views led to particular consequences. Schmoeckel's position is accepted here only to the extent that the presentation of Schmitt's opinions is treated firstly in purely analytical terms.

[end of page 42]

It has to be said that, at least until 1941, it is quite clear that Schmitt regarded the evolution of Germany's foreign and military policy as perfectly compatible with his theory and, presumably, an implementation of it. So he refers to a German-Russian Frontier and Friendship Treaty of 28 September 1939 as setting the boundaries of the both Reichs' interest in the territory of the former Polish state.73 This is a clear reference to the outer boundary of the German Grossraum as being that of the beginning 
of the Soviet or Russian Grossraum. He regards the German-Russian treaty as a clear exposition of how two Grossräume apply the principle of nonintervention. Article 2 of the Treaty expressly rejects the possible of the intervention of any third power in the Agreement. The Introduction to the Treaty stresses that the Peoples (Völkerschaften) living in these regions should have their integrity protected in "ihrer völkischen Eigenart" (their national particularity) This is to mean the destruction of the Versailles system of so-called minority treaties for this region. For the Baltic Region and Romania, treaties for the resettlement of Germans in the Reich have been concluded in the course of 1939-40. Equally important, the GermanItalian Arbitration of 30 August 1940 had assured a correct reshaping of the Hungarian-Romanian border from the standpoint of a just Volksordnung. At the same time agreements have been made with the Hungarian, Bulgarian, and Romanian governments for the protection of German minorities, which deliberately fly in the face of the liberal-democratic Versailles minority rights system. The latter is firmly rejected.

Schmitt concludes that all of this practice confirms 74 the basic principle of non-intervention of Powers foreign to the Region as a valid principle of international law concerning minority group rights.

The question that has to be asked is by what sleight of hand does Schmitt dispose of the fate of Poland. How does Schmitt explain the German aggression against Poland and its subsequent terrorization? The answer is that Schmitt passes this over. After the war, in August 1945, Schmitt produced a legal opinion on behalf of Friedrich Frick, who expected to be brought before the Nuremberg Tribunal as a major war criminal. In this opinion there is mention not of the attack upon Poland but of the legal situation in the summer of 1939. The question whether the concept of an attack (Angriffskrieg) would be regarded as illegal was answered effectively in the negative by all states. The governments of all countries not involved in the conflict declared their neutrality and passed neutrality laws. This was a classical international law reaction that meant that the traditional view of the place of war in international law was maintained, i.e. no distinction could be made between a just and an unjust

73. C. Schmitt, Völkerrechtliche Grossraumordung (1941), reproduced in Maschke (Schmitt: Staat, Grossraum, Nomos), supra note 13, at 295.

74. Id.

[end of page 43]

war.75 It can surely be extrapolated from this opinion, when taken together with Schmitt's interpretation of the German-Soviet/Russian treaties that Schmitt interpreted the prohibition of intervention of so-called outside powers (Reiche) as extending to what he regarded, at the time, as the still normal operations of international law. These had to include the right of a state to go to war. If the German Reich regarded the ultimate recourse to the use of force as necessary for the maintenance or development of what he calls a 'Gerechte Volksordnung' (a just order of peoples) then an outside power has no status to object. Schmitt does not say this explicitly, but it is reasonable to put together his theory of Grossraum with his general theory with respect to war, which will be discussed in a later section.

Apart from individual amendments to his text Schmitt adds two full sections from 1939 until 1941, in response to criticism from figures in the $S S .76$ In the first new section, Reich und Raum, there is an unmistakably radical incorporation of the concept of colonialism into the structure of international law, although its implications for the contemporary situation in Europe are not spelled out. Continental European international 
lawyers, and particularly Germans, have remained trapped by the thinking about territory which is appropriate to small and middle-ranking states, i.e. the idea of territory as a self-enclosed space to be defended by a state-power (Staatsgewalt). This ignores substantial German and other historical research as to the true nature of the European international law system. This has rested upon the assumption that European states would draw a so-called friendship line beyond Europe where it was agreed that unbounded conflict over colonial possessions would not have legal repercussions for the European legal relations of states. This development was essential for the transformation of states such as France and Britain into Reiche.77 Germany was excluded from this colonial enterprise in 1919 and this had to mean the defamation and disqualification of Germany as a European Power.78 Schmitt gives only the slightest hint of what the political consequences of this analysis must be against the background of 1941 in Europe. The whole of European history is marked by the experience that states within the European system are allowed to expand with a kind of free hand in an area not taken to be part of the international legal community, for instance Austria in the Ottoman Balkans. This is the basis for Portugal, Spain, England, France, and Holland being Reiche and not simply states. For Russia there was the expansion against the Ottomans and in Central

75. C. Schmitt, Das internationalrechtliche Verbrechen des Angriffskrieges und der Grundsatz "Nullum crimen, nulla poena sine lege" (The international crime of a war of attack etc.), edited with notes and Afterword by H. Quaritsch, at 73-74 (1994).

76. A. Könen, Der Fall Carl Schmitt, at 796 (1995); see also Section 3.4, infra.

77. Schmitt (Völkerrechtliche Grossraumordung), supra note 73, at 312.

78. Id., at 315 .

[end of page 44]

Asia. Prussia was the only Great Power which was only a state and which could only expand at the expense of other states which already belonged to the European international law community. Hence it was easy for Prussia to acquire the reputation of a disturber of the peace and as a brutal power-oriented state (brutaler Machtstaat), even although the space it occupied was small in comparison with other Reiche. Schmitt says that "[i]n unseren Tagen, 1940, beginnt eine neue Raum- und Völkerordnung sich abzuheben [...]."”79

The League of Nations System has to be seen in this wider Raum-oriented context. The intention of the British and French Reiche was, through the Versailles status quo, to maintain their imperial division of the world. They showed through Italy's Abyssinia experience and the policy of non-intervention in the Spanish Civil War, that they were not able to maintain their system of international law, and most importantly, they were not able to construct new 'friendship lines,' i.e. zones outside the regime of European international law through which the growing Peoples (wachsende Völker) of Europe could be given a place for just 'peaceful change.' They pay for their failure not merely with the collapse of their status as world powers, but also with the collapse of an international law system which rested on them as leading Reiche, and which also rested on the spatial division of the Earth (Raumverteilung der Erde) which they had conceived.80

The next new section Der Raumbegriff in der Rechtswissenschaft appears much more theoretical than the first, with only hints of a political direction. Yet these hints appear unmistakable. Schmitt returns directly to his theme of konkrete Ordnung. A classical (17th century) theory of mathematical and natural-scientific knowledge favored the idea of state territory as an empty space, or as an object over which power was exercised. 
This resembled Kant's theory of knowledge, that the territory might be something whose shape was conferred on it by the perception of the state as the observing, acting subject.81 For the concrete approach to space, new biological thinking is more helpful. 'Movement' does not occur in a space. Rather the movement creates the space. From a biological perspective the world is not somehow in a space. Rather the space is in the world. Space is a product of happenings (Ereignisse) and comes out of the objects which are within it, instead of being merely a static location in which objects find themselves. So a first conclusion is 'Der Raum wird zum Leistungsraum' (the space becomes a space of performance). ${ }_{82}$ Schmitt is basing himself on the work of the Heidelberger biologist, Victor von Weizaecker.

79. "In our days, 1940, a new Order of Space and Peoples is beginning to arise." Id., at 310.

80. Id., at 313-314.

81. Id., at 318 .

82. Id., at 319 .

[end of page 45]

He concludes that such thinking is appropriate for his theory of concrete Order. Space as such is not a concrete Order. However, every concrete Order and Community must have a place and space which is specific to it. Here Schmitt returns to the Germanic idea of law developed since the Middle Ages. Land, according to Otto Brunner, writing in 1939, means the legal association of land-building and land-commanding people in their spatially concrete peaceful order (in ihrer auch räumlich konkreten Friedensordnung). ${ }_{83}$ However, Schmitt recognizes, at another point, that the "world is in a state of transition." He refers to "das grosse weltpolitische Geschehen der Gegenwart" (the great world-political events of the present) and notes difficulties of terminology have to do with our being in an in-between stage. As soon as the Earth has found for itself a secure and just division of Grossräume and these are established internally and externally, it will be possible to find more satisfactory ways of describing the new situation. 84

Such extraordinarily measured remarks that Schmitt adds to his work since 1939 change its character radically. In the first text, Reich und Raum, it is possible to see no more than an insistence that Germany will watch over the development of the principle of ethnic self-determination of peoples in eastern and south eastern Europe. This need involve no violation of the very existence of any state as sovereign. Only the Jews are regarded as artfremd and they do not have a state. There may be coercion towards a country that resists the German view of the nature of minorities, but there are no clear implications for Germany as a Reich. However, Schmitt develops this position decisively. A state becomes a Reich because other Reiche accept the idea of a 'peace-line' beyond which the state is free, without fear of intervention of other states, to expand in territory not regarded as part of the European international law community. The rules of European international law are suspended to allow the construction of colonial empires. These latter are the essential element that transforms a European state into a Reich, or world power - something that all major states aspire to, usually successfully. Where the attempt is made by major European Reiche to exclude one state from this process of transformation from state to Reich, it is only to be expected that the outcome will be an explosion of the whole system of international law. In the second text (Der Raumbegriff in der Rechtswissenschaft), Schmitt considers again the element of territory in the traditional definition of the state. The international legal order likes to present itself as resting upon the concept of territory as an empty space occupied by a static state power. 
However, communities shape law and space therefore receives its significance from active, performing communities. Their 'movement' has to take place, to be somewhere, and it is their activity that gives this 'somewhere' order. Unless this dynamic is recognized and integrated into the concrete

83. Id.

84. Id., at $314-315$

[end of page 46]

legal order, it is inevitable that those who have already given lines of division to the world's space will find these lines sprung from the outside by a Reich which has been forcibly excluded from an active part in the shaping of the world's space.

It will be necessary to return to these implications which Schmitt implies for the integrity of international law because of its ambiguous perspective towards the non-Western world. They are expounded in the course of and at the end of World War II. However, at this stage, approaching his views chronologically it is intended to turn to his development of ideas concerning the concept of war and international law. This brings one back in time to the years before the war, where Schmitt's theories of space had not yet been fully developed.

His concept of war, however, evolves into a changing concept of the nature of war at sea and the nature of total war. The same evolution is affected by his concept of Law as Nomos and becomes a fuller critique of international law. The central point of the critique is that the Earth lacks a Nomos. Schmitt attempts to argue that the failure to resolve the place of Germany as a Reich does not allow Europeans to escape the fact that their theory of imperialism undermines the integrity of their universalist concept of international law and leaves world society without any legal shape.

\subsection{The turn to a discriminating concept of war, and total war on land and sea}

Schmitt is concerned that the determination of the Western powers to maintain the status quo created by the Versailler Diktat will lead them to undermine the whole conceptual framework of international law. He has already characterized World War I as a determination of the West to impose its view of society upon the Central Powers. Now he takes up a major theme of his original study on Nationalsozialismus und Völkerrecht, the liberal, formalist reduction of international law to a sanction procedure that reduces the concept of war to that of a peace-enforcement action. Schmitt develops immediately the theme that built into the liberal approach to international law is the desire to turn the violence of inter-state war into that of an international civil war. 85 The liberal concept of legalization of relations does now require that if one is to speak of a just war in a relativist and agnostic age, one cannot return to the world of scholastic philosophy or of Grotius. The League of Nations is a 'Legalisierungssystem' (legalization), which has to claim a monopoly of decision over whether a war is just, and what remedies may be applied. However, in the face of the crisis of the late 1930s, the question arises how to ensure a 'Positivisierung' (positivisation) of the League Order so that it becomes a real constitution with the procedures for effective collective action. Here 
Schmitt is conscious that scholarship is now concerned to go beyond the apparently purely logical constructions of a constitution of the international community which were current in the 1920s, in particular in the work of Verdross, Die Verfassung der Völkerrechtsgemeinschaft (Constitution of the international law community) from 1926.86

This drive to go beyond Austrian-style logical normativism to effective institutionalism is, in the work of George Scelle and Hersch Lauterpacht, firmly based in a liberal-democratic Weltanschauung. One is arguing not simply for a logical primacy of international law, but for a primacy of a legal order above states which is radically individualistic and democratic. George Scelle moves, in the French Legalist tradition, in the direction of an international legislative order.87 In turn, Hersch Lauterpacht also dethrones the state in favor of a civitas maxima, with a universal common law and an international judiciary at the center.8s Despite the difference in emphasis and style between the French and the English, they both aim for a universalized and institutionalized World Legal Order, in particular a liberal-democratic international law.89

This can be seen clearly in the work of Scelle. For him the state is a fiction, as the only legal subject is the human individual. The state is transformed from anthropomorphism or ancient metaphysics into a collection of governing persons who owe their competence to delegation by international norms. Institutions which till now regarded themselves as purely national find that they depend entirely upon an international order which constitutes the last instance, 'Kompetenz-Kompetenz.' This draws very heavily upon Kelsen's normative system, but now Scelle goes beyond him in giving the norm a dynamic sufficient to create an institution. He moves beyond Triepel's notion that the different state wills can reach a general agreement to the idea of particular individuals being granted competence to create international legislative acts. There is no question of looking to the problem of the binding nature of treaties. Instead, the question is simply which individuals are given the competence to issue legislation. This is simply the transfer onto the international level of the legislative model of the 19th century liberal constitutionalism, the sole function of which remains the defense of the life, liberty and property of the individual.90

As one has to do with Weltanschauungen one must expect aggressive action. Scelle is perfectly aware of the defects of the existing League of Nations structure, but it is clear to him that under article 11 of its Statute it would be open to the League to intervene in Germany against the treatment of the Jews. Interventions in Nationalist Socialist Germany,

86. Id., at $2-4$.

87. Id., at $10-11$.

88. Id.

89. Id.

90. Id., at $12-14$.

[end of page 48]

bolshevist Russia, and fascist Italy would all be justified and fail to be undertaken only for political reasons. The individual has a legal right to resist any act of his state that is contrary to international law. This marks, in Schmitt's view, the transformation of inter-state wars to civil wars.91 There is a polar link between liberal individualism and international law universalism, which give as a final goal an internationalized federal world order. Dictatorships and non-liberal states shadow such a historical development. War, as a legal concept, becomes impossible. There is either law and no war or there is war and illegality (Unrecht), i.e. as an illegal attack (Angriffskrieg), a crime.92 
Schmitt considers that the developments in question have to be seen in epochal terms. Already during the World War the intention of liberal propaganda was to turn the war into an 'executing action' against the criminality of the German government, albeit not strictly against the German people. However, the German people as a whole were able to resist this perspective, which leaves us with the traditional concept of war, as not illegal but outside the law.93 Here it is extremely important to hold the new institutional approach to international law to the letter. It is not enough to take goals as having been reached, as one might read out of the works of Scelle, Lauterpacht, Fischer Williams, and McNair. One cannot simply talk about just or unjust war. So the Kellogg-Briand Pact is not enough on its own to put the classical legal concept of war aside. There has to be a binding monopoly of decision-making actually already standing above states and clearly able to enforce itself against non-party states.94 To pretend that one is almost there in terms of institutionalization is extremely dangerous, because it ignores the capacity of numerous states to resist effectively the implementation of this vision as German resistance in the World War showed. Underlying this belief in a supposedly last step forward is a vision of universalism to be reached by means of a world federal state. Yet, stresses Schmitt, this is precisely the issue in dispute. 95

So any future conflict around such an issue of Weltanschauung will be all the more ferocious. For those states that think they represent a World Federal State in the making, the enemy state will now be a bandit, gangster-state, without any worth or honor. This is a turning of interna-

91. Id., at 16-17.

92. Id., at 19, 21. The same determination to develop and overcome the defects of the League can be seen in the work of Fischer Williams, who makes the most of the English tradition of surmounting legislative defects through resort to effective practice, all in the same direction, to ensure effective collective military action, in the aftermath of the Abyssinia crisis. Coercion and force are not abolished but they are collectivised and denationalised. Realistically, not every state has to act against a violation of the collective statute, of the League, but they are allowed to, and the violator cannot plead that any state has the right to be treated as a neutral in relation to him. Id., at 28-31, 35 .

93. Schmitt (Die Wendung zum diskriminierenden Kriegsbegriff), supra note 67, at 46-49.

94. Id., at 48 .

95. Id., at 50-51.

[end of page 49]

tional war to civil war, but without the actual dismantling of state-organized peoples. Yet the effective treatment of war now as civil war must only intensify the concept of enemy which is in play. There is a total definition of the enemy who has now been reduced to the status of a robber and pirate. 96 German international law doctrine has perceived since the middle of the 1930s the danger of total war that underlies pacifist universalism. This is a world picture (Weltbild) which is opposed to the German concept of a political-pluralist view of world society. The universalist ideology must lead to a concept of Vernichtungskrieg (war of annihilation) which has as its object the springing apart of the enemy state, the destruction of its government, in the style of civil war conflict. An executing action against a rebel or, in terms of civilization, backward country - these are all ideas present in the Allied thinking in their war against Germany in 1914-1918.97

Schmitt concludes that the only outcome of the very confused French and English thinking will be to leave the international community without any coherent framework of the place of war in international law and, hence, without any framework of law in international society. The crucial mistaken assumption upon which all of these authors work is that it is possible to go from an unclear and unrealistic view of the League of 
Nations to the concept of a universal world order.98 Clearly for Schmitt there appears to run through his text the expectation that the conflicting perspectives will lead to a repetition of history and that Germany will once again be treated as criminal. He sees this as a logical outcome of the Weltanschauung that is determined to treat war as a denationalized form of international sanction. Those who represent this view must come up against states that oppose it, i.e. dictatorships, whether fascist, nazi, or bolshevist. To persist in their view they (those who are liberal pacifists) have to wage a total war, not a limited war among combatant armies. This total war must serve a civil war style function to separate the people of these robber, pirate states from their governments. Such total war has to lead to a reconstitution of the existing state order but, as said already, with the ferocity of a long drawn out international civil war, in which the final result could be generations away. 99

The fundamental dividing point is so intense because, underlying the denationalizing of war, there is a whole liberal-democratic perspective, Weltanschauung, which is opposing itself to what it regards as an outmoded, metaphysical view of the state, to collectivist concepts of Volksgruppen identity, as well as to bolshevist forms of social-economic organization. None of this is to say that this Weltanschauung has immediate aggressive intentions. However, it is irreconcilably opposed to

96. Id., at $48-50$.

97. Id., at 43,52 .

98. Id., at 53 .

99. Id., at $45-46$.

[end of page 50]

anything but its own universalist program. Furthermore, it clearly intends, as a matter of urgency, to put its own program into place on the international scene. It regards opposition to its program as rooted in the internal ideological constitution of other states. Unless it gives up its project, immediately a matter of transforming the League of Nations, global conflict is inevitable. Schmitt does not draw explicitly these conclusions. Yet he appears to expect history to repeat itself.

With respect to the development of ius in bello, Schmitt's preoccupation is primarily with England and the United States, powers which he puts together as Anglo-American and sometimes, Anglo-Saxon. France disappears as an ideological opponent. Indeed, Schmitt is even praiseworthy of the French representation of what he considers the continental perspective to war. It has its origins in the construction of the French state that was the first example of a territorially enclosed state dedicated to limited territorial wars engaging only official state combatants. 100 Louis XIV completed France's adherence to this style of warfare with the dismissal of Colbert in 1672, marking France as a land rather than a sea power.101

What is crucial here is that Schmitt moves into the treatment of the ius in bello in terms of his theory about the influence of space upon the law. In the first instance he is not original and follows a well understood continental complaint about the impact of sea power on England's concept of warfare. Many German international lawyers carefully developed this complaint in the years immediately preceding World War II. Schmitt distances himself from such an approach and complains that it fails to appreciate that the perspective of the land-based, and virtually land-locked state was not appropriate for a Germany aiming to break out of these confines to reach the status of a Reich with its own Grossraum.102 For this purpose it was necessary to come to terms with the full implications 
of the Anglo-American concepts of space-determined warfare.

Consistent with his theory that Law is a matter of the perception,

Weltanschauung, of the subject, virtually a personal matter, Schmitt develops the English approach to war at sea. It is traditionally a function of an ideology apparently quite primitive in its early stages, but providing quite clear roots for the present ideology of Anglo-Americanism. The argument is immensely complex and not necessarily logical in all its stages, but then the responsibility for that rests not with Schmitt but with AngloAmerican legal culture.

The starting point is the construction of the English Empire from the

100. C. Schmitt, Raum und Grossraum im Völkerrecht, 24 Zeitschrift für Völkerrecht 145 (1940), at $153-154$.

101. C. Schmitt, Land und Meer. Eine weltgeschichtliche Betrachtung (Land and Sea: A WorldHistorical Reflection) 53 (1981).

102. Schmitt (Raum und Grossraum im Völkerrecht), supra note 100, at 171-172, where he quotes Admiral Raeder declaring his intention to imitate American policy in April 1940.

[end of page 51]

time of Queen Elisabeth until the Treaty of Utrecht. During this time the English undertook a plunder of the Spanish and Portuguese Empires primarily through the activities of privateers acting upon their own initiative.

War at sea was condoned by royal authority but was not a

state-sponsored or controlled activity. The Crown benefited very substantially and honored its privateers, but this essentially economic warfare did not implicate the construction of an English state. Instead, this activity built up English strength on the basis that the seas were a space in which there should be the fullest private economic activity unhindered by state regulation. The function of English official power becomes that of ensuring that no other so-called state power obstructs the full expansion of any private, even if effectively English maritime trade. 103 This analysis brings Schmitt back to what he regards as the English version of Grossraum for the country conceived of as a Reich. It is not enough that English naval power will remain in the background to ensure that no other state attempts to monopolize the sea and restrain English commerce. This was merely the first stage of resistance to Spanish and Portuguese pretensions. Indeed, in the 17th century England also displayed monopolist pretensions to appropriate the sea. However, English maritime technical genius moved it in a different direction. It proved supreme, not in the occupation of the sea, as if it were land, but in the mastery, through superior shipmanship, navigation, and naval warfare, in the negotiation of elements which were not to be mastered in the sense of occupied, but merely ridden and directed in the sense of natural elements. 104 Such power provided a basis for an English insistence upon the acquisition of supporting points, naval bases, strategic territories etc., all of which came to make up a colonial Empire, stretching across the Earth (always a capital for Schmitt). 105

However, even this does not alter the original character of England's proposal for the world. The freedom of the seas is universal. It covers the South China Sea as much as the Baltic. It affects the entire character of the Mediterranean. ${ }_{106}$ It is the foundation for an ideology that dictates that

103. Schmitt presents this historical perspective in Land und Meer as its main thesis. But see, especially, Schmitt (Land und Meer), supra note 101, 40-46, 52-53; and C. Schmitt, Staatliche Souveränität und freies Meer (State Sovereignty and Open Sea) (1941) included in Maschke (Schmitt: Staat, Grossraum, Nomos), supra note 13, at 407-416, concerning the opposition of land and sea in modern international law.

104. Schmitt (Land und Meer), id., at 86-95. The English genius was to realise that the sea was an element requiring "a different approach" to land.

105. Id., at 94. This irritates Schmitt's sense of space, as it leads to a world empire which is 
scattered all over the Earth, without any system in terms of a geography of land. However, Schmitt appreciates that this does not matter. Land is incidental to the economic and hence political power which the control of the seas gives. He quotes Sir Walter Raleigh: "Who commands the seas, commands the trade of the world, and whoever commands the trade of the world also owns all the treasures of the world and, in fact, the world itself." Id., at 87.

106. Schmitt (Raum und Grossraum im Völkerrecht), supra note 100, at 169-170.

[end of page 52]

the international legal order is about the facilitation of a liberal world economy untrammeled by considerations of State and Volk. The language of liberty means liberty of trade, but accompanying it are other individual rights to property, opinion, and movement. No state can claim any right to resist this ideology. No space in the world is immune to its penetration. ${ }_{107}$ In the late 19th century Germany began to resist this ideology. The language of dualism in law developed by Triepel is intended to provide a wall of state resistance. The primacy of state law over international law is the first stage in the struggle of particular states to provide resistance. 108 Yet, the struggle for world economic power could not be conducted from within the confines of the territories of European states.

The question of Grossraum is originally economic. It concerns whether there can be devised a larger form of economic space which can provide an alternative to the world economic space of the English ${ }_{109}$ and, increasingly, by the turn of the century, the Americans. For Schmitt, America is a maritime power and natural associate of England not because of similarities of language and history, but rather because America is not threatened by any neighbor along its land frontiers.110 These two powers agree upon a concept of world space which is liberal, economic and, at the same time, universal. In principle, there is no part of the world that is immune. The Anglo-Americans do not occupy the seas. Instead, they ensure that the seas are the way to a total opening of the world. It is now, writing in 1940 to 1942, crucial for Schmitt to understand how the Anglo-Americans treat maritime space in the event of conflict. It is already established practice that the freedom of the seas, with complete freedom of commerce, becomes in the event of war freedom to conduct total war against not merely all the private resources of the immediate enemy, but also against the private resources of any states which attempt to trade with the enemy. Total blockade of the enemy and, hence, total economic warfare against the entire population of the enemy is appropriate and to be expected. It is not to be expected that Schmitt will object to all of this as a peculiarly inhuman Weltanschauung. Humanity is not a matter that interests Schmitt. Indeed, Schmitt will object that warfare is all the worse for being waged in the name of a humanitarian vision of the freedom of the individual. Rather, the totality, even shapelessness, of the AngloAmerican concept of warfare has to be seen in terms of the absence of a developed concept of the state which would view conflict as taking place within confined territorial spaces. The continental state tradition of limiting such conflicts to state combatant forces would be essential if there was to

107. Id., at 161-164. Schmitt's resistance to an economic ideology is paramount: "[w]here uncontrolled private commerce ends, there ends also the methods of British or anglo-saxon world dominance." Id., at 164.

108. Id., at 164 et seq.

109. Id., at 146 et seq.

110. Schmitt (Land und Meer), supra note 103, at 100-102.

[end of page 53]

be anything left to achieve in a final victory in the confined European space. For the Anglo-American, warfare was, in the first instance, e.g. in struggles against Holland in the 17th century, about the destruction of the 
economic wealth and power of rivals. Later warfare could be given a more ideological tone concerning the immediate restoration of an unhindered global space for the economic individual. This should, obviously, given the function of ideology, be seen as meaning the same thing as it did in the 17 th century wars. Warfare whose motive is primarily economic will seek the destruction of the economic foundations of the opponent, in this definite sense, total warfare.111

Schmitt doubts the ideological efficacy of German international law resistance to this legal ideology when it confines itself to objecting that the English do not observe the continental concept of warfare, based upon the desire of the rather narrowly territorially confined state to preserve itself after the conflict, which it has, in any case, voluntarily entered in a kind of power-game, war as politics by other means. Offensive wars of conquest are not a necessary part of Anglo-American international law ideology, except in the very broadly defensive and incidental sense of keeping world trading routes open. So, the ideological opposition from the continent has to be in terms of an understanding of the universalist nature of the ever expanding Anglo-American Grossraum. Some way has to be found to persuade it to withdraw into limits that allow a place for other Grossräume.112

Schmitt does not develop a full, alternative concept of ius in bello. However, he does offer two points for consideration. First, AngloAmerican legal ideology is not neutral or pluralistic over against other ideologies. It supposes for itself a supreme moral, humanitarian authority. This leads to a virtually schizophrenic attitude to alternative ideologies. Its first tendency to respond is isolationist. That is, the alternative is so disapproved of that contact is not sought at all. Isolationism is a common feature of English and American foreign policy. It is obviously influenced by an insular sense of space, but it is much more marked by a sense of moral superiority which does not allow itself to be contaminated by entanglements - quarrels - which are of an inferior quality, i.e. about essentially insignificant territorial disputes, with inferior powers which

111. Schmitt (Land und Meer), supra note 103, at 88, regarding the extent of the conflict as waged by a sea-power. See also C. Schmitt, Staatliche Souveränität, reproduced in Maschke (Schmitt: Staat, Grossraum, Nomos), supra note 13, at 419 et seq., for a discussion of the incapacity of England to approach conflicts in terms of the parameters of the state.

112. Schmitt (Land und Meer), supra note 103, at 80-85. Schmitt sees Germany as a loser both at land and at sea. It was kept out of the great land-seizures (Landnahme) of the New World, and was itself the subject of land-seizures within Europe, a play-ground for a battle between world-Catholicism and world-Protestantism, in which it could not decide its place. The non-Jesuit catholic Germans and the Lutheran, non-Calvinist Germans were not able to retain a space for themselves. Indeed Lutheranism's small-territory orientation is contemporaneous with the disappearance of German sea-power, the Hanseatic Baltic Sea power.

[end of page 54]

suppose that they can change their status significantly by seizing relatively small portions of territory. The difficulty is that when such morally superior powers find themselves drawn into conflict they do not regard their opponents as moral equals. The very foundation for the classical European concept of warfare is absent. It is not a matter of two state powers choosing to resolve a relatively minor territorial or status difference by resorting to a duel-like 'armed-combat.' Instead, it is a matter of destroying, as economically as possible, forces which appear to dare to upset the indisputably moral world order based upon the full expression of the economic freedom of the individual. Hence, such conflicts are not bounded by any classical concepts of war limitation at all. The liberal humanitarian isolationist restraint turns quickly to the most furious conduct of total war, aiming at the complete obliteration of the enemy. If any response to this 
ideology is possible at all it has to be in terms of an alternative concept of Grossraum.113

Second, Schmitt tends in favor of a technological imperative of total war. Grossraum is originally an economic concept. It has been developed in German literature since the turn of the century around notions such as Mitteleuropa and has encouraged Germany to search for its economic space. This is thought out in terms of the impact of radical technological change on the nature of economic power. 114 Schmitt does not look to a concept of Lebensraum in territorial terms of land for settlement, at least at this point. Anglo-American concepts of Grossraum cannot be opposed with a concept that is merely an extension of the traditional continental concept of a self-enclosed territorial state. Instead, the German Reich has to appeal to the idea that it preserves a space of freedom for Peoples, to allow them to develop their particularity in distinctive ways. He cites an Irish author (without reference) who says that universalism makes the smaller Peoples chickens in the kitchen of the cosmopolitan restaurant. 115 It can also be recognized, more positively, that the traditional AngloAmerican dominance of the sea, the root of its economy-driven individualist ideology, is itself now put in question by technological developments, especially in terms of aviation and air warfare. It is now a fact that the sea can be the subject of control the same as land.116

However, apart from resistance to the Anglo-American view that its ideological writ may run worldwide across all seas, Schmitt does not offer any picture of how the effects of armed conflict might be limited. The matter does not appear to concern him. The struggle between Grossräume concerns the relative merits of their underlying political ideas. The means

113. C. Schmitt, Die letzte globale Linie (The Last Global Line) (1943), reproduced in Maschke (Schmitt: Staat, Grossraum, Nomos), supra note 13, at 441-448. In this paper the connection is made with the terms in the last part of Die Wendung zum diskriminierenden

Kriegsbegriff, concentrating now exclusively on the sense of moral mission of America.

114. Schmitt (Raum und Grossraum im Völkerrecht), supra note 100, at 146 et seq.

115. Id., at $178-179$.

116. Id., at 151. See also Schmitt (Land und Meer), supra note 103, 98-99 and 106-107.

[end of page 55]

to uphold these will include, to put it quite banally, the use of all 'modern technologies.' At least that is the impression one obtains from his discussion of the economic origins of the concept of Grossraum and his belief that the distinctiveness of the Anglo-American hold over the seas is diminishing. ${ }_{117}$ However, the goal of the German Reich is not total. It is to force the British and Americans to withdraw from global dominance to their own spaces, to allow the co-existence of several Grossräume.118

\subsection{Imperialism and the loss of nomos}

Already by 1940 Schmitt had developed a clear conception of what a permanent world domination by Anglo-American liberal pacifism would mean for the structure of the traditional body of European international law.119 By the end of World War II these deliberations were incorporated into Der Nomos der Erde, although it was not published until 1950. However, the development of Schmitt's argument, now only remotely connected to National Socialism, is still related to the criticism of the liberal democratic state. Its imperialist proclivity is rooted in the hollowness of a parliamentarianism that is a system of legality without legitimacy. This has to be considered briefly before one can understand how it is that such a parliamentary state is imperialist. 
Writing about parliamentarianism in the 1920s Schmitt argues that the liberal concept of Law is a myth. In a mass society Parliament is dominated by powerful interest groups which find their expression in party factions. Each attempts to seize upon the ideological or rhetorical force of legality but this is nothing more than a dictatorship of an accidental majority over a numerical minority. 120 Legitimacy is absent in the sense that a conviction or sense of obligation from the people could only come through some appearance of direct democracy. That pressure will build up for direct democracy is inevitable because of the blockage represented by party factions and cartel or corporate style interest groups. The latter certainly seek to deck themselves in the rhetoric of a liberal legality, but the conflict between traditional legality and the desire for democratic legitimacy favors the bypassing of parliamentarianism in favor of authoritarian and even totalitarian style presidential government, if the legitimacy of political society is not to disintegrate entirely.121 Fascism and

117. Id., for Schmitt's discussion of the law of the air and of the sea in terms of the technical capacity of an airforce to dominate the sea. This seems to set a consistent tone for the perspective that technological power will be used to the full to ensure the triumph of the Weltanschauung of each Reich in its turn.

118. Id., at 179. See also Schmitt (Die letzte globale Linie), supra note 113, at 447.

119. C. Schmitt, Die Auflösung der europäischen Ordnung im Völkerrecht (The Decomposition of the European Order in International Law) (1940), reproduced in Maschke (Schmitt:

Staat, Grossraum, Nomos), supra note 13, at 372.

120. Schmitt (Die geistige Lage des heutigen Parlamentarismus), supra note 38, at 38 et seq.

121. Schmitt (Legalität und Legitimität), supra note 37, at 312 et seq.

[end of page 56]

bolshevism are attempts to respond to the socio-economic failure of the liberal democratic state, itself driven by economic interests in the form of cartels, which are not subject to any democratic political restraint. So, economic imperialism accompanies parliamentarian democracy and the question is how to oppose both.

Schmitt had already touched upon the forms of economic imperialism in 1932. The appearance of unrestricted international economic relations concealed a willingness, particularly by the United States, to use above all economic coercion to achieve an undisturbed operation of its vision. At this time Schmitt had in mind mainly the economic penalties which the Versailles Treaty imposed upon Germany and the manner in which Germany suffered economic warfare to the point of attempted starvation.122 By the end of the 1930s Schmitt expands this theory into a systematic critique of the destruction of the international law tradition.

At the international level, the bankruptcy of the liberal myth of Law showed itself decisively in the context of late 19th century colonialism, in particular with respect to Africa. Between the 16th and 19th centuries there was a specifically European international law. It rested upon a precarious Ethos, but one with a content. The word State signified the renaissance construction, which asserted absolute internal authority so as to put an end to murderous religious wars. 123 The legal order especially focused on the limitation of the effects of conflicts among sovereign princes. The laws of war concerned the ideological neutralization of political violence in international relations. A part of the latter had to be indifference to internal constitutions of states. 124 The liberal political revolutions, which Schmitt dates from 1848, gradually dissolved the Ethos of European international law. The insistence upon a priority for individual liberties, attached also to a free market economy, always understood itself as a universalizing ideology. The State is merely a framework for maintaining the stability of economic relations and the neutrality implied in the concept of the state is gone. It is instrumentalised by an expansionist, 
universalizing ideology, which is a cloak for the economic groups that capture the principle of legality in parliamentary factions.125 Until the 19th century the non-European world was a no-man's land which provided occasional theatres for the extension of European dynastic conflicts. Economic exploitation was intermittently fierce, but it did not have universalist pretensions in what was still a Eurocentric international

122. C. Schmitt, Völkerrechtliche Formen des modernen Imperialismus, in Schmitt (Positionen und Begriffe), supra note 11, at 162, where Schmitt begins by trying to undo the ideological impact of the argument that one can set the economic against the political. See also Ulmen, supra note 1, at 58 et seq.; Maschke (Drei Motive im Anti-Liberalismus), supra note 13 , at 71 .

123. Schmitt (Nomos der Erde), supra note 1, at 112 et seq.

124. Id., at 115 .

125. Schmitt (Legalität und Legitimität), supra note 37, at 343.

[end of page 57]

law.126 After the Congress of Berlin the European powers took the fateful step of saying that they had to incorporate the rest of the planet, in order to guarantee a global application of the rule of legality. They extended the concept of territorial sovereignty as they understood it in Europe to Africa, so that the territory of the African colonies had to be regarded as an integral part of European states. ${ }_{127}$ Further, Europe proceeded to treat the rest of the planet that it did not occupy as part of a global system of liberal legality, with the caveat that the remaining states were subjected to capitulations that were supposed to guarantee the same conditions of legality attaching to territorial sovereignty which European states themselves considered necessary. 128 The liberal concept of legality covers the entire earth through the temporary force of European arms but it does not rest on any sense of place in the new continents. Europeans themselves now lose any sense of place-located identity. In fact the extension of their European order now means, for instance, that the concept of recognition of new states, their admission to the European order, becomes a mere formality. Recognition came to mean nothing but a statement of confidence by other states as to the stability of the newly created situation. 129 The new global international law has become a rootless, i.e. not a place-bound system, an arbitrary juxtaposing of factual relations. There were fifty or more states, hardly any of which claimed to be exclusively European, given their imperialist-universal pretensions. They were completely heterogeneous, without common values. At the same time they laid claim to the rhetoric of liberal legality, above all, the equality of each state before the Law, and the sovereignty of each state which could only be bound by what it had agreed with others acting together. The fundamental weakness of this system is that states are no longer able to contain the possibilities of political violence through the classical doctrine of neutrality. This was to have devastating consequences for the civil wars that they came to wage among themselves. 130

Furthermore, at the international level the only source of new law that this system could offer would be treaties. Yet where any treaties at all could be concluded they were filled with so many reservations that, in their own terms, they could not even make the formal claim to constitute an international legal order. The development of law through general custom or precedent could only have an equally confusing effect. What sense could it have to transpose as precedents, for example, incidents between Belgium and Holland to Siam and Indo-China? The liberal tendency to abstraction and generalization would certainly try, but the 
128. Id., at 206-207.

129. Id., at 206 .

130. Id., at 201, 218-219.

[end of page 58]

outcome would be senseless for the concrete populations bound to the particular territories. 131

\section{Carl Schmitt as an Adviser of the Nazi Regime?}

\subsection{Introduction}

The view is widely held in Germany today that Schmitt wished, at the very least, to attract the attention and favor of the Nazi Regime with his theory of Grossraum. He is thereby taken to have approved of Hitler Germany's expansion policy towards the East. This discredits him professionally, so that there is no interest within the discipline of international law for his work. It has only a historical interest. 132 It is intended to explore this problem closely from the perspective that Schmitt's critique of AngloAmerican international law ideology continues to have acute actuality. For instance, an article in the English quality Sunday newspaper argues, inter alia, that

[t]he common enemy of the new political ideas of the Nineties is the voracious global market, which brings waves of downsizing and delayering, disruption and dislocation. How can a country engage with the global economy, and enjoy all the benefits that can bring, and yet retain a sense of social cohesion and civic culture? That is now the central question of politics $[\ldots] .133$

It is obviously the question that Schmitt has been addressing. No state or ethnic group is now able to challenge the 'depoliticized' global economic structures. The central thesis of this paper, as stated in the Introduction to Section I above, is that the spectacular conclusion of Hitler's Germany was the first stage in the establishment of the singular liberal hegemony which is supposed to mark the end of history. Hence, it is a central part of contemporary debate to attempt not only to unravel the contribution of Schmitt to the ideology of the Nazi Regime, but also to pose the question whether there is a seamless web running from his ideas to those of the Regime.

This question will be tackled in the wider terms of what it could mean, historically, to give international law advice to the Nazi Regime, particularly after 1938. Such an inquiry is not only relevant to the assessment of the guilt of Schmitt for the aggressive policies of the Regime, but also to the appraisal of the compatibility of Nazi Weltanschauung, as practiced by

131. Id., at 212 .

132. Even a historical work such as Schmoeckel's aroused considerable reservations, as a chosen topic, in the Faculty of Law in Munich where it was written. I was a visiting Alexander von Humbolt Fellow in Munich at the time the work was completed in 1993. 133. C. Leadbeater, What is the Big Idea? The Observer (4th August 1996).

[end of page 59]

its leading figures, especially Hitler, with any conceivable view of international law. This inquiry will lead into the more ambiguous territory of Schmitt's own relationship with the Regime. It will be taken as clear that he very much wished to influence it and to have his views accepted as the proper framework for a German Ostpolitik, which he particularly wished to justify to Anglo-American opponents. However, when it comes to a consideration of the merits of Schmitt's ideas, in comparison with 
those of the Regime's practitioners, it will be argued that assessment of the extent of his complicity with the Regime remains largely a matter of judgement. It depends upon whether one considers that he should not have tried to exercise influence upon it.

The roots of Schmitt's own Weltanschauung are very similar to Hitler's, in particular his understanding of the nature of the relationship of Law and Politics. This raises the question whether Schmitt was realistic, or, alternatively, sincere, in appearing to limit the international law outcomes of his analysis well behind the limits set by Hitler. Nonetheless, there seems to be no doubt that Schmitt and Hitler diverged radically both in the extent of their hostility to Anglo-Americanism and in their understanding of Germany's expansionist policy towards the East. This is not simply to be read out of the lack of detail in Schmitt's analysis of the Grossraum idea, i.e. its geographical extent and the manner in which it was to be administered. While such lack of clarity will be taken as grave, indicating also a lack of political seriousness and responsibility, the decisive points of divergence with Hitler appear in the definition of the place of war in relation to politics and in the issue whether a Grossraum should itself be a springboard to global dominance. Schmitt does offer a reasoned, in the sense of limited, critique of Anglo-American international law ideology that continues to have considerable credibility. To read into his work Hitler's own agenda is to engage in a form of conspiracy theory that violates both the ideas and structure of Schmitt's writing. Schmitt's aim was certainly not diagnostic in the sense of offering a merely contemporary historical snapshot of international society. He wished to be an adviser. However, he has to be credited with having failed!

\subsection{Carl Schmitt's writings as international law advice}

This issue was raised at Nuremberg. It is well known that Schmitt was accused of being an adviser to the Nazi Regime and that he denied the charge. The most interesting part of his response is his theoretical argument that the giving of legal advice to the Regime was to misunderstand the manner in which the Regime functioned. While this argument will be taken as demonstrably correct historically, it still leaves the question open how Schmitt could have thought his own writings compatible with the Regime's general Weltanschauung.

It is the attention that the Völkerrechtliche Grossraumordnung achieved abroad that appears to have marked him as a key adviser to the Regime.

[end of page 60]

The Times and the Daily Mail consider that Schmitt enjoys an official position as Hitler's key advisor, at least as someone who can be regarded as a trustworthy guide to a German policy that remains concealed. The outcome would be an Eastern Europe under German domination.134 Schmoeckel considers it obvious that the theory influenced Hitler, who made an enthusiastic reference to the Germans adopting their own Monroe Doctrine in his April 28th 1939 Reichstag speech in response to President Roosevelt's note to him of April 14th. Hitler spoke of Lebensraum rather than Grossraum but in Schmoeockel's view the formulation and thought is clearly taken by Hitler from Schmitt. Strangely, Schmoeckel adds that he accepts the view that the borrowing was not direct, that Hitler would have picked up the idea from the foreign press and somehow would have imagined that the idea was originally his. The reason for this rather abstruse interpretation of the influence of Schmitt was the report that he received a warning from a member of the Regime that Hitler regarded 
the idea as his own, and that Schmitt had better not be heard to disabuse him. ${ }_{135}$ One can hardly have imagined that Schmitt, wanting to exercise influence in Regime circles would have been so indiscreet to have entered into open argument on such a point, but it might also be doubted whether the member of the Regime was giving a necessary warning. He might have known of the example of Ribbentrop. One of the ways in which Ribbentrop managed to exercise considerable influence on Hitler

was the gift of storing away in his memory pet ideas of the Führer and then introducing them on later occasions as ideas of his own - a procedure which could not but persuade Hitler that Ribbentrop was a man of discernment and judgement [...]." 136

In any event, Schmitt quickly wrote another short paper in which he praises the effectiveness of Hitler's speech without claiming any credit for it.137 The crucial question for the international lawyer, when faced with this meticulous tracing of historical influences, is whether Schmitt can be taken to have acquiesced in, or openly approved of the methods which Hitler intended to use to achieve his Grossraum, i.e., to be precise, aggressive war against Poland, and, later, the Soviet Union. At Nuremberg in 1947, Schmitt was interrogated primarily on the strength of his participation in

134. Maschke (Schmitt: Staat, Grossraum, Nomos), supra note 13, at 347, for comments of the Editor.

135. Schmoeckel, supra note 7, at 139-140.

136. G.A. Craig, The German Foreign Office from Neurath to Ribbentrop, in G.A. Craig \& F.Gilbert (Eds.), The Diplomats 1919-1939 (1994), at 406, 420.

137. Maschke (Schmitt: Staat, Grossraum, Nomos), supra note 13, at 348. Maschke refers to Schmitt's article Grossraum gegen Universalismus: Der völkerrechtliche Kampf um die Monroe Doktrin, published ten days after Hitler's speech, and reproduced in Schmitt (Positionen und Begriffe), supra note 11, esp. at 302. Maschke attributes influence on the actual writing of the speech to have come from the international lawyer Fritz Berber who was the close legal assistant to Ribbentrop. Id., at 347.

[end of page 61]

the debate on Grossraumordnung. ${ }_{138}$ Schmitt had clearly stated in his rejoinder to Hitler's speech that the purpose of a German adoption of the Monroe doctrine was to ensure a 'living together' of peoples (Zusammenleben) in spite of the pressure of a universalist ideology. 139 Bendersky is impatient with the idea that Schmitt could be taken to have advocated war or conquest, or even to have fostered the foreign policy aims of Nazi ideology. 140 The first part of this statement may be true, in the absence of evidence to the contrary. However, Schmitt continued to regard the waging of war (Angriffskrieg) as still allowed under international law, at least in 1939, and indeed as part of the structure of any viable system of such law.141 The second part of Bendersky's statement goes too far. All of Schmitt's writings after 1939 are based upon an enthusiastic anticipation of the outcome of German attempts to break out of its 'Kleinstaatlichkeit' (status as a small state) and achieve a definitive Grossraum no longer contested by the Anglo-American world. The essential part of this debate, in Schmitt's view, did not have to be whether the Grossraum was based upon racial foundations, but whether its principle would be conceded by Germany's most serious protagonists, Britain and America. In trying to take issue with these two countries Schmitt was hardly showing Hitler's anglophilia. Hitler's most passionate objective was to persuade Britain and America not to frustrate or stand in the way of his drive to the East.142 The most that Schmitt's writing could have done would have been to persuade a few intellectuals that these countries were in fact Germany's bitterest opponents. 143 So it is likely that Schmitt is fair in claiming, as he does, that "what is decisive is the distinction between 
the intention to promote scholarly research and knowledge and that to

138. J.W. Bendersky, Carl Schmitt at Nuremberg, 72 Telos 91 (1987), at 97, including a transcript of the interrogation.

139. Schmitt (Positionen und Begriffe), supra note 11, at 302

140. Bendersky, supra note 138 , at 93.

141. Schmitt (Das internationalrechtliche Verbrechen des Angriffkrieges), supra note 75. See also E. Freiherr von Medem (Ed.), C. Schmitt: Glossarium Aufzeichnungen der Jahre 1947-1951 (Carl Schmitt: Diary Notes 1947-1951), at 120-121 (1991), diary entry of 3 April 1948, where he reaffirms this opinion given in August 1945 in a letter to Wilhelm Grewe. Throughout these diaries Schmitt repeatedly holds to the view that a "war of attack" is not illegal in international law.

142. See, e.g., J.C. Fest, Hitler, at 827 (1996).

143. Schmitt (Glossarium), supra note 141, at 164, where he says that Hitler's final political goal was an Anschluss with the British Empire, entrance to this well regarded Firm, and thus participation in the British agony and euthanasia. These diary notes, published after Schmitt's death, show no remorse for his own participation in National Socialism, but they do appear to show bitterness that Hitler did not appreciate where the true enemy lay. For instance, he says that Germany fought two wars, a non-discriminatory one against the West and a discriminatory one against the East; id., at 117. For Schmitt the latter type of war contradicted his system of international law. It had to mean turning inter-state war into colonial and civil war; id., at 29. So it is consistent that he describes Hitler's attack on the Soviet Union as foolish. It could blow up the whole world; id., at 15 . He remains unrepentant against the United States. The so-called World War II began not on 1st September 1939 but with the collapse of the New York Stock Exchange in October 1929; id., at 103.

[end of page 62]

promote practical goals and achieve practical results [...]." ${ }_{144}$ None of this is to say that Schmitt did not support the general war aims of the Regime, i.e. that war was necessary for Germany to break out of its small-territorial state status. What this implied was a matter of opinion where scholarship could play a role. It has to be recognized that there was some measure of debate and intellectual freedom in the Third Reich. It was a matter of having protection from somewhere within the Regime. Schmitt had Görings's protection. In 1936 the desire of Schmitt's $S S$ enemies had been to drive him out of academic life altogether. Heydrich and Himmler continued personally to try to win over Göring. However, he remained supportive of Schmitt till the end.145

At another point Schmitt accepts that the intellectual habitus of the scholar is to further knowledge and, as well, the exchange of opinion. There is a danger that in times of open or latent civil war every word will be at once changed into a propaganda slogan. He accepts that every author is responsible for every idle word, but objects that in legal terms it had been decided at Nuremberg that not even Hitler's Mein Kampf constituted criminal planning as such. 146 At the same time Schmitt was thoroughly within the German side of the war. There is, of course, in particular, Schmitt's already noted adoption of the Soviet-German Agreement of September 1939 concerning spheres of influence, which clearly endorses the extinction of Poland. One can say that Schmitt's distinction between support for a regime and responsibility of the scholar meant that he thought he had a better idea as to what the Regime should be trying to achieve. Schmitt's responsibility in the matter of Hitler's foreign policy is more usefully seen in terms of reflection on how Schmitt thought his theory of law, as applied to international law, was supposed to have any constructive influence, whether in the sense of advice, solicited or not, on Hitler. This question calls for a consideration of his views of the power-holders in the Regime alongside his views of the nature of Law as a

Konkretesordnungsdenken as opposed to the hated Normativismus of the Liberals. Once again, it is embarrassing to read of Schmitt's view of powerholders in 1947, given that he is one of the most celebrated proponents of the authoritarian state, and given that his theory of Konkretesordnungsdenken 
is linked to his theory of decisionism, which supposes the authority of the Leader. Nonetheless, the interest of the analysis offered here is to determine not simply the integrity of Schmitt, in a personal sense (threatened with trial, why should he incriminate himself) but also the integrity of his system of thought, which is, in Western international law terms, original and attempts to provide an alternative to the monolith of liberal-democratic international law.

144. Bendersky, supra note 138 , at 115 .

145. Könen, supra note 76 , at 753 . Könen reports that Schmitt shared Göring's opera box in February 1943.

146. "You collaborated in the preparation of wars of aggression and therewith were party to criminal offences at decisive points." Bendersky, supra note 138, at 128-129.

[end of page 63]

When Schmitt says that he deliberately kept his distance from the real center of power (Hitler and his circle) that he "was prompted by the general dread of power holders and their cohorts, and the abiding conviction that discussions with them are unproductive [...]." 147 this is contradicted by history. Yet another example of association is the fact that he sent a copy of his essay Die Wendung zum diskriminierenden Kriegsbegriff to Ribbentrop, who replied that he would be very pleased to find the time to read what Schmitt had to say on such an important theme in a free hour.148 However, this change of tune by Schmitt is not as significant theoretically as his apparent rejection of the whole decisionist approach to law, which is explicit in his criticism of the definition of the position of the Chief of the Reich Chancellery, Martin Bormann. Schmitt contrasts the minimum which can be expected in the functioning of public authorities to adhere to forms and norms and what he calls a certain legality of methods, in the French and German sense of the word. "Legality is the functioning modus of every state bureaucracy [...]." ${ }_{149}$ Yet characteristic of the Hitler Regime is its completely personalized rule of secret orders and secret laws, central to the arcana of the Hitler regime. ${ }_{150}$ Hitler is characterized as having only the deepest hatred for any stipulations through forms or even institutions [...]. His deliberative subjectiveness and therewith the fundamental abnormality of his regime is really unprecedented $[\ldots]$ - a system that knew no binding forms and institutions, in which everything it did or announced was always "subject to change." The fundamental irreconcilability of the omnipotence of the Fuehrer and the legalizing order of the state was thus perhaps most obvious in the position of the Chief of the Reich Chancellery [...]." 151

This is a fundamental concession by Schmitt, and if it cannot be qualified it undermines the integrity of his approach to international law, given the place which Schmitt accords to the Leader.152 One need only recollect the

147. Bendersky, supra note 138, at 117 (Testimony - A Propos the Question of the Position of Reich Minister and Chief of the Reich Chancellery: Observations from the Standpoint of Constitutional law).

148. Könen, supra note 76, at 786. The association would not be random, if one takes into account Ribbentrop's preference for accommodation with the Soviet Union.

149. Bendersky, supra note 138 , at 120.

150. Id.

151. Id., at 122

152. Of course his view sits uncomfortably with such a text as C. Schmitt, Der Führer schützt das Recht (The Führer Defends the Law) (1934), included in Schmitt (Positionen und Begriffe), supra note 11, at 199, which is a defence of the murder of Röhm and his followers. See B. Rüthers, Carl Schmitt im Dritten Reich, at 53 (1989). It can easily be argued, however, that Schmitt was simply disappointed with the choice he made to support Hitler. In 1950 he went on to write a study of the Spanish authoritarian mid-19th century figure, Donoso Cortes in C. Schmitt, Gesamteuropäischer Interpretation. Vier Aufsätze (1950). In the Glossarium there is the ironical comment that Hitler owed his success to the mythical figure of the unknown soldier which came out of World War I, a democratic symbol; see Schmitt (Glossarium), supra note 141, at 267. 
importance of the act of the Führer as a defense against Powers which are foreign to the space and which do not rest on the völkische principle. 153 Hitler's aversion to Normativism is crucial both to his entire foreign policy and to his appeal to Germans as a radical intellectual. As has been seen, the heart of the concept of Konkretesrechtsdenken in international law is that the law must, somehow, reflect the concrete life of Peoples. Yet it is in Der Führer schüzt das Recht that Schmitt claims

[t]he judgeship of the Führer springs from the same legal source from which springs all the Law of the People. In the case of greatest necessity the supreme Law protects itself and appears as the highest standard of judicially vengeful realization of this Law. All Law stems from the right of life of the People [...]."154

This aspect of Schmitt's thinking, given his recantation in 1947, has to be explored more fully in the context of the conduct of foreign policy and the place of international law.

\subsection{Hitler as a model for Schmitt, the theorist of legal authority}

While it is not the object of this paper to do more than explain in general outline Schmitt's approach to international law in the period 1933-45, something has to be said of the hope which Schmitt obviously had for Hitler, well advised by Schmitt. Where is there the common ground? The hostility to liberal democracy is an essential part of the Nazi Weltanschauung. The reason for Schmitt's willingness to resort to the authoritarian rather than the liberal state had to do with his fear of and contempt for liberal middle class politics. It lacked the grandeur and heroism of the old order of the monarchy, the state civil service and the army. It was torn by endless intrigues over the balancing of so-called interests of particular groupings that were tearing the state apart. The State (i.e. the Army and the Civil Service) Schmitt regarded as having disintegrated with the defeat of 1918 and the abdication of the Monarchy.

The State came to be restored by the Nazi Movement with its Leader. The Movement and the Leader restored the German State. ${ }_{155}$ However, a commitment to such a leader as Hitler was no accident. Hitler was a reflection of numerous characteristics of inter-war Germany that Schmitt also reflected. 156 The similarities are innumerable.

Hitler's radicalism was attractive precisely because of his hostility to and indifference to all existing power relations, including the international constraints that appeared to be imposed upon Germany. It was not only Schmitt but also Hitler who triumphed at the idea that a decision could be taken out of nothing. As Fest puts it, Hitler

153. Rüthers, supra note 152, at 85 .

154. Schmitt (Positionen und Begriffe), supra note 11, at 200

155. Schmitt (Staat, Bewegung, Volk), supra note 52, at 32 et seq.

156. Fest, supra note 142, at 22.

[end of page 65]

knew nothing of the sense or rightness of what had become established. While other statesmen took account of the reality of existing power relations, he began from an empty surface. So he constructed Europe and the World from a new starting point; he came from nothing and he thought from nothing. 157

This runs parallel to Schmitt's focus upon the State of Exception, where the state suspends the whole of the existing legal order. The Decision (Entscheidung) makes itself free from any normative boundedness and is Absolute. 158 The Decision itself is born out of nothing, considered from the normative perspective. From the aspect of content every moment of 
decision is something new and strange (Fremdes).159 The thinking of Schmitt and Hitler run parallel, above all in their radicality, even if we see that, possibly, Schmitt may not have intended this to go so far in international relations.

It is essential to penetrate the language of Weltanschauung and Konkretesrechtsdenken to the nature of the radicalism underlying it. I have attempted to introduce Jaspers in order to argue that the former concept is deeply rooted in the radical subjectivism of German idealism. With respect to Schmitt's legal theory this theme is particularly focused on the deep anxiety which has afflicted the German People about the instability of its place in any European order of Peoples. The crucial existential element in his thought about the Volk has been seen to have very close parallels to Hegel. It is possible to draw a direct line between a passage of the Concept of the Political and a passage of Hegel's Philosophy of Right to illustrate the nature of an existential conflict between peoples. So, Schmitt says that normal moral standards could never justify killing. States, however, come inevitably into mortal conflict with one another where their way of life is threatened. All of these deliberations are in the context of a theoretical discussion of war and the impossibility of limiting it - a main ground of Schmitt's opposition to the English and French international lawyers whom he discusses. Schmitt says:

War, the readiness of combatants to die, the physical killing of human beings who belong on the side of the enemy - all of this has no normative meaning, but an existential meaning only [...]. There exists no rational purpose, no norm, no matter how true $[\ldots]$ no legitimacy nor legality which could justify men killing each other for this reason. If such physical destruction of human life is not motivated by an existential threat to one's way of life, then it cannot be justified [...]." 160

Hegel's parallel remarks are set within a context of the inevitability of war among states, that is, a war which is traditional not total. Hegel states:

157. Id., at 1029 .

158. C. Schmitt, Politische Theologie. Vier Kapitel zur Lehre von der Souveränität, at 19 (1934).

159. Id., at 42 .

160. C. Schmitt, The Concept of the Political (Translation, Introduction, and Notes by G.

Schwab, with Comments on Schmitt's Essay by Leo Strauss), at 49 (1976).

[end of page 66]

The welfare of a state has claims to recognition totally different from those of the welfare of the individual. The ethical substance, the state, has its determinate being, i.e. its right, directly embodied in something existent, something not abstract but concrete, and the principle of its conduct and behavior can only be this concrete existent and not one of the many universal thoughts supposed to be moral commands $[\ldots] .161$

In the 1920s Schmitt prepares the ground for the radicalism of his perspective with respect to the Volk.162 Schmitt's vision of Germany goes back to the extreme conflicts of the German peasant War and the Wars of Religion. Conflict till death is supposed to be a reality. We are bound to one another in the state by the fact that it can afford us the occasion for a meaningful death, a constant in German history. 163 In the context of post 1918 Germany, the famous civil war of the 20th century, following the Russian revolution, gave Schmitt the choice of national or class conflict as myths with which to 'glorify' violence or 'irrationality.' 164 Schmitt distinguishes himself from what he sees as the contemplative dialectic of Hegel, when he describes the destruction of the bourgeois liberal world in his work on parliamentarianism. He follows directly Sorel's reflections on violence and reverts to his concept of myth, beyond any rational deliberation, in order to place nationalism above communism: "From the depths of a true Life-instinct, not from mere reasoning or calculation, arises great enthusiasm, great moral decisions and great myths [...]." ${ }_{165}$ The vital strength of the People means the superiority of the national over the class 
myth shown by the victory in Italy of Sorel's pupil, Mussolini.166

161. G.W.F. Hegel, Philosophy of Right (Translation with notes by T.M. Knox) (1967), at para. 337-340. See M. Kaufmann, Recht ohne Regel? Die philosophischen Prinzipien in Carl Schmitt's Staats und Rechtslehre 59-60 (1988), where this parallel is highlighted. See also J. Rückert, Der Rechtsbegriff der Deutschen Rechtsgeschichte in der NS-Zeit: der Sieg des 'Lebens und des konkreten Ordnungsdenken,' seine Vorgeschichte und seine Nachwirkungen, in J. Rückert \& D. Willoweit (Eds.), Die Deutsche Rechtsgeschichte in der NS-Zeit (The Concept of Legal History in the National Socialism Period) (1995), at 177 and 186-187, citing also Kaufmann's work, but claiming that it considers too much the philosophical and not legal context. For the history of international law, in particular the concepts of Volk, Staat, and War, the argument here is that the tradition of philosophical idealism is crucial both for Schmitt and for Hitler.

162. The analysis which follows is based entirely upon Kaufmann, supra note 161. I have also analysed the more sociological approach of Christian von Krockow, which places Schmitt's existentialism in the social milieu of the 1920s German academic in another publication. See Carty (Interwar German Theories), supra note 40, at 1270 et seq.

163. Kaufmann, supra note 161, 61-62 and 71-73, mentioning also the literature on how far Schmitt simply dabbled with cloak and dagger political melodrama.

164. The use of the concept of civil war to describe Nazi/Fascist-Soviet antagonism is a major controversial theme of the so-called 'Historiker-Streit' in Germany in the 1980s, particularly between Ernst Nolte and Jürgen Habermas. The attempt to equate the two opposing ideologies as engaged in a civil war was thought by some as an apology for the Nazis. See E.R. Piper (Ed.), Historiker-Streit (1987).

165. Schmitt (Die geistige Lage des heutigen Parlamentarismus), supra note 38, at 56; cited in shorter form in Kaufmann, supra note 161, at 95.

166. Kaufmann, supra note 161, at 96.

[end of page 67]

What is problematic for any international order is the subjective quality of this construction. The cult of irrationality is built into the concept of Weltanschauung. It means for Schmitt precisely that it does not matter whether what is believed is true, only that it should lend strength to the political act. Concretely this means a belief in the historical destiny of a People. This is developed further after 1933 in Staat Bewegung Volk, where Schmitt insists that the unifying force of the myth require the leadership of the Party and Führer to give unity to the People, the latter being understood passively.167 Clearly Schmitt is putting life forms (Lebensformen), essentially ethnic difference, above a parliamentary interest politics, where differences could be resolved through compromise. This is not simply because of an aggressive anthropology, but also because of Schmitt's assumption that basic concepts such as Freedom, Rechtstaat and Democracy could only have their precise meaning from a concrete antithesis. 168 In the end Schmitt is dissolving all constitutional forms into one final source of legitimacy in the self-determining will of the People, so that the Volk is understood existentially. ${ }_{169}$ Its active status, as has been seen, depends entirely upon the Führer.

What is crucial is that, beyond generalities about Volkstümlichkeit, Schmitt is professing a radical anthropology of a society in an advanced state of disintegration due to evil, meaning by that, aggressive, exploitative, untrustworthy/unreliable conduct that induces an equally radical anxiety and sense of threat in social relations. The question is whether or how this can be overcome, short of a miracle. The answer is that a dictatorship is necessary to overcome moral chaos. As Kaufmann remarks, this authoritarian state will set itself above any constitutional restraints, as it is whipped up into an enthusiastic crowd held together by myth and dramatic action. It will refuse any explanation in its march to destroy so-called 'staatszerstörenden Kräfte' (forces destructive of the state).170 Therefore there is no saving objectivity for international law in institutionalized konkretes Rechtsdenken. For Schmitt his theory receives further support from a French source, the constitutional theorist, Hauriou. The latter, in turn, draws upon Durkheim and Duguit. The objective 
legal norm is for Hauriou precisely the reflection of a perspective

(Widerspiegelung einer Anschauung) from a particular social milieu.171 In

his case he was thinking primarily of the esprit de corps of the Conseil d'Etat. Hauriou does not accept simply the doctrine that the legal norm, of itself, shapes the law. One has to consider the manner in which the legal system is grounded. The leading idea (Leitidee) of an institution is something objective, present in the institution, an agreed declaration of

167. Id., at $97-99$.

168. Id., at 226-231, 235-236.

169. Id., at 316 .

170. Id., at 324, 326.

171. Kaufmann, supra note 161, at 359-360.

[end of page 68]

community (übereinstimmende Bekundungen von Gemeinsamkeit), which does have a particular group within the community as the carrier of the idea.172 Whatever force the legal idea may have comes from the legal substance of family, the state or the army. Out of their particular ideas a rule of law may emerge. For the international lawyer, i.e. Schmitt, it is seen as possible to adapt Hauriou's ideas by looking to the Volk that is itself held in legal form by the Führer.173 It is the leading idea of the Volk which the regional power, Germany, has to protect against outside intervention. Kaufmann, who is making these scholarly connections, quotes here from the essay on the Reichsbegriff. This Reich is defined in terms of a Grossraum which is ruled by a particular Weltanschauung, itself guaranteed by a People equal to the task.174 After explaining how Hitler understood the same ideas, it will be necessary to return, in a last section, to the question whether one can distinguish Schmitt's position from 'full-blooded' National Socialism.

What will be suggested about Hitler concerns his existential appeal, his radicality, how this affected his attitude to rules, law and with it, European order and international law. Lebensraum (living space) rather than Grossraum was Hitler's key revolutionary concept with which to change Germany's small territorial state status. The interest of this analysis has to be confined to one question: how far the attractiveness of Hitler for a figure such as Schmitt implicates the picture of the latter as an international lawyer and makes out of him a National Socialist international lawyer.

The primary difficulty is how can a supposedly existentialist perspective be compatible with any normative perspective? Must Schmitt not have realized that to put the decision before the norm was to express, in Hitler's case, a revolutionary dimension which was not compatible with Schmitt's vision of Germany as a regional power, with rights equal to other regional powers? Hitler's fierce energy and radicality he attributed himself to being completely without resources or position, someone that had to create everything for himself out of nothing. Hence Hitler's approach to the valid rules of the game was not simply the defiance of social convention found with Gregor Strasser or Joseph Göbbels. Hitler had about him the radical subjectivity which Schmitt notices in 1947, the unwillingness to tolerate any idea above himself, with a tendency to ignore all apparently objective restraints. 175 In the atmosphere of acute anxiety that the middle classes experienced after 1918, Hitler played deliberately the theme that 'nothing has any longer an anchor.' The intensity of anxiety is such that whole

172. Id.

173. In a conversation with Maschke, the latter suggested, Schmitt firmly believed that reality could be given shape by legal forms which intellectuals such as he could devise. The shapelessness of the Nazi Regime could take form through Schmitt's thought. 
174. Kaufmann, supra note 161, at 367. See also Schmitt (Positionen und Begriffe), supra note 11 , at 311-312.

175. Fest, supra note 142 , at $17-23$.

[end of page 69]

masses of people feel a catastrophic power of uncertainty. Hitler knew to incorporate in himself the fears of the Germans: "The thinking of our People is uneasy and hasty. Life itself is completely torn apart [...]." 176 This led Hitler not to a search for inner authenticity (Echtheit), but to a belief in such total social disintegration that life had to be a struggle of all against all. Law, morality, humanity, or whatever, had to give way to the relentless law of nature that was the rage for self-preservation. In international relations this meant the struggle of peoples for Lebensraum (Lebenskampf der Völker). This struggle experienced the most fanatical radicality, with the maximum of ruthlessness, where no restraints existed between war and annihilation. 177 It is not easy to gather how Schmitt could have seen such existentialism as capable of restoring, as he seemed to wish, the traditional Europe-limited struggles for Great Power status. 178 In such a radical perspective Hitler never understood the concept of Lebensraum as a simple claim to a limited regional status for Germany. It was also not simply a rational device to provide Germany with needed natural resources. It was a test for the Germans on their way to a world leadership and domination. Over against the Versailles System and the pre-1914 international order in which Germany found itself, Lebensraum meant the complete overthrow of Germany's European environment, which could only limit and restrict it. Hitler's determination to dominate and resettle the Russian heartland meant a belief in the possibility of overturning the migrations of peoples that were thousands of years past. An absolute radicality of the project was to be combined with an equally fanatical disregard in the implementation of the project. As became obvious by the end of World War II, Hitler's plans were carried out with an unprecedented rigor. The catastrophic sense of existential anxiety that grounded his plans provoked their execution in a manner that reached apocalyptic levels of horror. 179 It is difficult to see how a serious political analyst cannot have realized, and therefore have acquiesced, in the relentless dynamic with which the concepts of Leader, People and Lebensraum, or Grossraum were laden. The absence of a clear dividing line, where such concepts are rooted in radical instability of social structures, is bound to leave the legal analyst wondering what can, in

176. Id., at 297, with a quotation from a speech.

177. Id., at $298-300$.

178. In the Glossarium Schmitt takes up the theme of nihilism to explain himself in relation to Hitler. What happened after 1918? From the darkness of a social, moral and intellectual nothingness, came a totally empty individual who sucked himself full with the words and affects of the educated Germany of the time. His spirit was an animal earnestness in handling affects and formulae. In return these educated Germans, till then confined to purely imagined affects and formulae, were surprised and happy to be taken seriously. There was now a person taking the matter seriously (Ernstmacher) an executioner of till then pure ideas. In particular Schmitt writes of "[t]he pure man of action (Täter), the pure function of the action, the work without belief." See Schmitt (Glossarium), supra note 141, at 149 , diary entry of 15 May 1948.

179. Fest, supra note 142, 306-310, 517-520 and 527.

[end of page 70]

retrospect, be extracted from a Schmittian project which appears a mixture of extreme naiveté and irresponsibility. 180 This conclusion cannot be left standing without a word for the thesis that Schmitt had the intention to provide a limited alternative project to Hitler's which he hoped could exercise influence. 181 


\subsection{Schmitt as a conservative revolutionary}

A stalwart defense of Schmitt's relationship to the National Socialist Regime could be in terms that he is to be seen as a conservative revolutionary, or even as a traditional German nationalist, part of a class of people who were in more or less effective coalition with the Nazis until the beginning of 1938. This is the time when von Ribbentrop at the Foreign Ministry replaced von Neurath and Keitel replaced von Blomberg and von Fritsch, at the head of the Army. These removals followed their unenthusiastic response to Hitler's explanation of his intentions to undertake aggressive war at a Secret Conference of the 5th November 1937. With this final Putsch Hitler considered he had effectively broken the power of the traditional pillars or Stände of the Prussian German state, the Civil Service and the Officer Corps of the Army. ${ }_{182}$ Schmitt is well known to have been toppled from his official positions about a year earlier, in December 1936, when Himmler, Heydrich, and the SS attacked him as an opportunist, not really committed to the Regime ideology of antiSemitism, and still influenced by catholic ideas of political society. 183 So, Schmitt wrote Völkerrechtliche Grossraumordnung when he had no official position in the Regime and was not, on the face of it, doing more than accepting invitations to give academic lectures, in this case, at the Kiel Institute of International Law in April 1939.

Did the Regime regard Schmitt's international law writing, particularly the Völkerrechtliche Grossraumordnung, as an acceptable continuation of the Conservative alliance? What was the reaction of the regime, in ideological terms, to Schmitt's Grossraum? Schmoeckel claims that Schmitt's theory of Grossraumordnung was tied to the ideology of Nazi Germany and to the present world war, which was to give it its Nomos. The sheer vagueness of the concept must have suited the Regime, and the claim to an equal status with an American Grossraum favored an expansionist

180. The arguments of von Krockow that Schmitt belonged to an un-political, dreaming world of the academic, in the worst sense of the latter word, have already been explored: see Carty (Interwar German Theories), supra note 40, 1258 et seq., 1269 et seq.

181. Schmitt does not apply his argument against retroactive rules of international law to the atrocities committed by the Regime. These are mala in se. See Schmitt (Das internationalrechtliche Verbrechen des Angriffkrieges), supra note 75, at 16. The planned killings and inhuman cruelty towards defenceless victims are of a crudeness and bestiality which go beyond normal human imagination. They are of a monstrous dimension which blow apart all traditional standards of international and criminal law, a scelus infandum. 182. Fest, supra note 142 , at $742-848$.

183. The now standard account of this is Könen, supra note 76, at 631 et seq.

[end of page 71]

foreign policy. By offering a theory for a policy of expansion, Schmitt strengthened an otherwise chaotic discussion of an eastern policy. Schmitt wanted to work on the shape of the coming war just as much as any apologist of international legal Unrecht. He did not make himself legally responsible for aggressive war, but he belongs among those whom Thomas Mann accuses of providing a foundation for the Regime. ${ }_{184}$ Schmoeckel concludes these speculations with the remark that "[i]t cannot, therefore, be excluded that the Grossraum doctrine contributed to put to sleep the consciousness of illegality in Germany." 185

This analysis is accompanied by the remarkable judgement that radical lack of clarity existed within the Regime about what its Eastern policy was, even as the war progressed. Schmoeckel cites the views of Himmler, Göbbels, Rosenberg, and others as if their opinions were all of the same value in an inconclusive academic discussion. 186 It is much more realistic 
to recognize that only a few people's opinions matter. Himmler comes first, with his self-assumed responsibility for overseeing the extermination of Jews and numerous Slav populations, with a view to a systematic resettlement of Germans in the whole, vast Eurasian landmass which was to be the foundation of a new Euro-Asiatic Gross Reich. In Himmler's operational planning, following on the overall territorial aims of the Wehrmacht, there was no lack of clarity. 187 It is equally notorious that Hitler was perfectly clear in his intentions, as he was to carry them out, towards the East. 188

The difficulty with Schmoeckel's analysis is probably that it is more legal than historical. He makes an elaborate investigation of all the legal writing subsequent to Schmitt's own intervention to see whether any correspondence can be reached as to the use of the key words, Raum, Reich, Grossraum, Politische Idee, Grossraumordnung, etc. He divides approaches into those which rely more upon the state as a starting point and those which rely upon the Volk, assuming that Schmitt himself more favored the former concept. This is because Schmitt was not willing to develop a full racial theory of Law and continued to maintain the need of a place for the State in social organization. Schmoeckel's study is comprehensive but it is legal, at least in the sense of stressing logical analysis.

$\mathrm{He}$ is trying, in the first German attempt of its kind, to take the heat out of the discussion of such a theme as Schmitt's international law theory

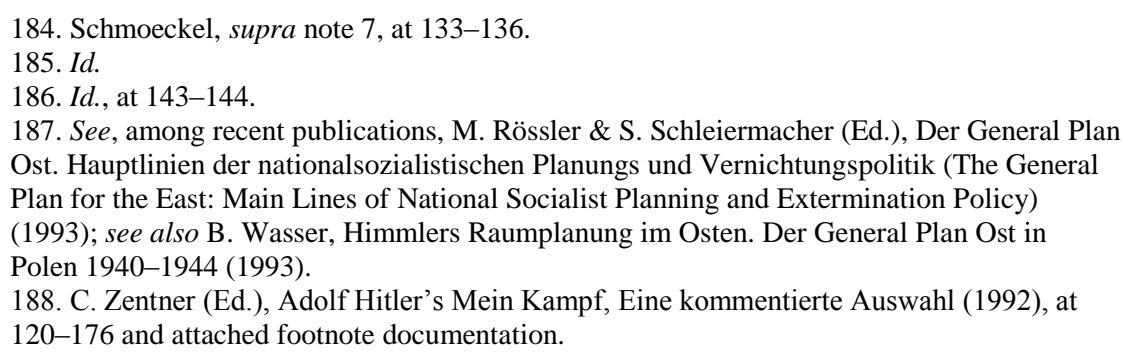

by applying standards of orthodox legal scholarship to his analysis. However, the result lacks focus on those figures who are representative of the Regime, and whose approval or disapproval would indicate how close to the Regime Schmitt actually was. 189

Könen attempts an apology of Schmitt in terms that his international law writing. Particularly Die Völkerrechtliche Grossraumordnung was a late leftover of the conservative or Christian or nationalist elements which had originally attempted to steer the Regime when, for instance, von Papen was appointed vice-chancellor in 1933. He focuses upon those attacks from within the $S S$, and the Regime generally, which were politically significant. This approach reveals that by summer 1941 Schmitt could not help but realize that he was never going to influence events in his direction. SS Führer Werner Best, a very high ranking official in occupied Denmark, insisted upon a völkische Grossraumordnung, which is related to the Weltanschauung of Peoples as "überpersönlichen, überzeitlichen Gesamtwesenheiten" (somehow superpersonal, beyond time as collective entities). 190 Instead of an international law Grossraumordnung, one must speak of a völkische order. It was such attacks that Schmitt responded to with his additions in the later editions. Firstly he added the section "Reich und Raum." This led to a further attack from Best, insisting again upon his völkische Ordnung. He sees in the connection that Schmitt makes with the Christian-European international law of the 16th century, a great political danger. Schmitt's concept of international law could mean that what 
had been subjects of the former international legal order might now claim equality as sovereign partners with the Leading People, and even bring their international law ties with that People to an end. Therewith Schmitt is branded as someone who tries to undermine the 'lebensgezsetzlich' (life-legislated) legitimated German claim to leadership.191

SS Führer Höhn joined in the attack, arguing as well that Schmitt's theory of non-intervention could be interpreted not merely outwards against interventions by foreign Great Powers, but also against the Leading People, the Germans, who would equally be prohibited from intervening in other Grossräume. 192 The principle of non-intervention may have a role in the foundation of a Grossraum, but must not later be allowed to lead to the defeat of völkische particularity. The Grossraum must be able to serve the Lebensgesetzlichkeit of Peoples and overcome artificial limitations. The function of National Socialist legal doctrine must be to

189. Schmoeckel, supra note 7 , at 152-240 (Part C).

190. Könen, supra note 76, at 796-801.

191. Id.

192. Id., at 801-804. All of this can be found in Schmoekel's analysis but it is broken up into individual conceptual sections, so, for instance one finds what Höhn has to say about the concept of intervention put alongside the comments of another Nazi international lawyer, Gustav Adolf Walz, a friend of Schmitt: see Schmoekel, supra note 7, at 229-230, for a very sharp analysis of almost theological abstruseness. In this case Schmitt's vanity should have been immensely satisfied at having provoked so much debate. Maybe it was!

[end of page 73]

emphasize that the political fighting concept of Grossraum is concerned with the claim to a more extended Lebensraum, which takes account of the needs of existence of European Peoples. With the destruction of English and French political and military chains, this new political order of Europe, based on the Lebensrechten der Völker, recognizes the need for new structuring of Space in accordance with the Life and Performancedrive of Peoples. Indeed a further danger of drawing on a concept of Law taken from the Monroe Doctrine is that the very idea of non-intervention attaches to an individualist concept of the state, which seeks to minimize the intervention of the state. A true Grossraum principle must be drawn from the spirit of a politically awakened People. 193 These criticisms of 1940 and 1941 were accompanied by one from the Rosenberg Office on 16th April 1941, which stated that it accepted Schmitt's theory of Grossraum positively, but with qualifications. 194 These attached to the use of the word Reich for the German Grossraumordnung. This difficult concept, if applied to the political order that the Reich leads, could entail such a level of abstraction as to be quite separated from the German People. ${ }_{195}$ Schmitt is taken by Könen to have recognized at this point that all was lost. He complained to a friend about the lack of a real public and the excommunication of intelligence. He brought out one last edition in July 1941, with a new chapter, "Raumbegriff in der Rechtswissenschaft." He stated in the forward that a new international law concept with a global political significance is likely to become a slogan or a term of abuse. 196

After attempting to place Schmitt in a very broadly European and Christian movement of thought throughout the 1920s and 1930s, Könen ends on a very controversial note that needs to be explored. He claims there is a definite message in these terms for the present, which necessitates some final, if brief, mention of what was the conservative revolutionary spirit. Könen claims that the heart of the Conservative Revolution was opposition to the prognosticated collapse of Western civilization, in particular the theses of Oswald Spengler, in his Decline of the West.197 The movement understood itself as the counter-revolution to '1789' and wished 
to establish on the continent of Europe a Christian Reich. They sought to achieve this through the construction of a spiritual basis for a lasting institutional foundation for human existence, i.e. one that did not rest simply on an interest-based democratic politics. 198 The attempts to construct a spiritual concept of People, with a place for inspired Leadership would fall within this more general framework. Individualist, materialist

193. Id., at $801-804$.

194. Id., at $818-819$.

195. Id.

196. Id.

197. See, e.g., F. Stern, The Politics of Cultural Despair: A Study of the Rise of the German Ideology (1961), at 183 et seq., on Möller van den Bruck and the Third Reich.

198. Könen, supra note 76, at 832-833.

[end of page 74]

democracy can bring nothing but pork barrel 'dealing' politics, for the most part completely blocked, inactive and stagnant. Schmitt was a key figure in this movement because of his sharp criticism of the liberal distinction between state and society and its roots in humanism, rationalism, and the Enlightenment. Instead he offered a status (Stand) oriented concrete order, which is most clearly set out in Staat, Bewegung, Volk.199 It has been seen how Schmitt attached to the Führer and the Nazi Party the responsibility for making up the deficiencies of the Hegelian state, in particular the directionless Army and Civil Service. It has also been seen how Hitler disposed of this assigned role. The expectation which Könen still places on the Conservative Revolution for the present time is one, albeit limited, way in which one might consider the continued relevance of the Schmittian international law vision in the present era of triumphant liberalism, which is supposed to mark the End of History.

Könen stresses the degree to which Schmitt's international law concept was primarily rooted in a European tradition of the subject, the ius publicum Europaeum. This is supposed to signify that Europe as a cultural entity could still be developed as a project in opposition to the rampant individualist materialism of Anglo-American democracy. He quotes Christian Social Union (Bavarian) political opinion that the old Reich (The Holy Roman Empire) could be a model for a common European home, in which the regions of Europe related to one another in quite a lose structure. 200 If this Europe is to be more than a mere uniform market, it should be able to reconnect with pre-national Europe. As such Europe could be more than merely an economic model.201 Another thinker, the Karlsruhe cultural philosopher, Peter Sloterdijk is well known in America for his monumental Critique of Cynical Reason.202 He is taken to suggest that the way to overcome a momentary 'Reichslosigkeit' (absence of the Reich) is through a continuation of the centuries-old struggle between modernisationglobalisation and conservationist anti-global forces. The motive of the Conservative Revolution, two to three generations ago, in Catholic Middle and Southern Europe, has a great future now in its religious, cultural, and regionalist aspirations. Globalization is bursting asunder the quasi-religious nation state that dominated Europe since the 19th century. Europe as an idea can be a response. For this it has to develop again the old concept of Reich. A European is someone who can undertake to redevelop this concept for the present day.203 Whether or not Schmitt really envisaged his concept of Reich in such European terms, a reactivation of a pre-national idea of the old Empire is most doubtful. Schmoeckel sees the central historical roots of Schmitt's 
concept of Reich in his response to the work of Christoph Steding, Das Reich und die Krankheit der europäischen Kultur (The Reich and the sickness of European culture) a part of the debate about how to resist Spenglerian decadence, especially as represented by liberal democracy.204 A Reich has to be founded not on ideas of federalism or confederation, but on a spiritual basis. Political forms must concretize objective standards of morality and reason.205 This places the focus on the quality of the spiritual critique that Schmitt, supposedly as a Conservative Revolutionary, was able to make of National Socialism. However, in a study which is devoted to a very sympathetic analysis of the Conservation Revolution's project for Christian Europe, Faber is categorical that Schmitt had no place in this current of thought during the Third Reich. Schmitt clearly envisaged a hegemonic role for Germany as leader of what is still a Europe of the nations.206 After the war it may have been another matter for Schmitt. Faber refers to an article in 1950 entitled Raum und Rom in which Schmitt says the words are the same.207 Finally, a contemporary of Schmitt's who regarded himself as a conservative revolutionary, with a project of a united Christian Europe, also puts Schmitt out of this company. In his focus on the destruction of the moral elements of German society by the Nazis, Rauschning places Schmitt foremost among those who blocked any possibility for moral restraint. Schmitt is seen to propose a theory of Leadership whose authority rested upon race and violence. 208 This negative conclusion is consistent with the critique of the foundations that have been made of Schmitt's own project for a European order. They rest upon Volk, Führer, and Reich. These ideas implicate him in the disasters of the Reich. His responsibility is limited because this Reich was a more plural entity than might sometimes be realized. However, all the international lawyer seems to be left with is Schmitt's very sharp negative critique of Anglo-American international law. If this were to be developed further through Schmitt's work then some more favorable interpretation would have to be put on his liberalism-critique than it has been possible to give in this study.

204. Schmoeckel, supra note 7, at 91-95.

205. Id.

206. R. Faber, Abendland. Ein politischer Kampfbegriff (The West: A Concept for Political Struggle) (1979), at 202 et seq. Schmitt's concept is German imperialist and involved the subjection of non-Reich peoples, with the continuous possibility of intervention. Schmitt's project was for a German supremacy, with England excluded from Europe. The American defeat of Germany meant, precisely, a restoration of the 1918-1919 liberal democratic domestic and international constitution which the counter-revolution of 1933-34 was intended to defeat.

207. Id., at 209.

208. H. Rauschning, Die Revolution des Nihilismus 169-170 (1938). 